\title{
AMPA Receptor Flip/Flop Mutants Affecting Deactivation, Desensitization, and Modulation by Cyclothiazide, Aniracetam, and Thiocyanate
}

\author{
Kathryn M. Partin, ${ }^{a}$ Mark W. Fleck, ${ }^{a}$ and Mark L. Mayer \\ Laboratory of Cellular and Molecular Neurophysiology, National Institute of Child Health and Human Development, \\ National Institutes of Health, Bethesda, Maryland 20892-4495
}

\begin{abstract}
AMPA receptor GluRA subunits with mutations at position 750 , a residue shown previously to control allosteric regulation by cyclothiazide, were analyzed for modulation of deactivation and desensitization by cyclothiazide, aniracetam, and thiocyanate. Point mutations from Ser to Asn, Ala, Asp, Gly, Gln, Met, Cys, Thr, Leu, Val, and Tyr were constructed in GluRA flip. The last four of these mutants were not functional; $S_{750} D$ was active only in the presence of cyclothiazide, and the remaining mutants exhibited altered rates of deactivation and desensitization for control responses to glutamate, and showed differential
\end{abstract}

modulation by cyclothiazide and aniracetam. Results from kinetic analysis are consistent with aniracetam and cyclothiazide acting via distinct mechanisms. Our experiments demonstrate for the first time the functional importance of residue 750 in regulating intrinsic channel-gating kinetics and emphasize the biological significance of alternative splicing in the M3-M4 extracellular loop.

Key words: glutamate receptors; cyclothiazide; aniracetam; thiocyanate; mutagenesis; AMPA; desensitization; deactivation; alternative splicing; flip and flop
AMPA subtype ionotropic glutamate receptors are assembled from subunits encoded by multiple gene families that are differentially expressed in subpopulations of neurons and glia (Boulter et al., 1990; Keinänen et al., 1990; Hollmann and Heinemann, 1994). The wide variety of functionally distinct native AMPA receptor responses recorded in CNS tissue (Burnashev et al., 1992; Jonas and Sakmann, 1992; Raman and Trussell, 1992; Livsey et al., 1993) is likely to result from assembly of different combinations of subunits. The results of single-cell PCR analyses provide strong support for this hypothesis (Lambolez et al., 1992; Bochet et al., 1994; Geiger et al., 1995) and suggest that the kinetics of excitatory postsynaptic currents in individual cells, which are determined by a combination of receptor deactivation, desensitization, and the rate of recovery from the desensitized state (Edmonds et al., 1995; Trussell and Otis, 1996), must also be controlled by subunit composition.

Recent studies on memory- and cognition-enhancing drugs implicate AMPA receptors as their underlying target of action (Staubli et al., 1994a,b; Zivkovic et al., 1995). Cognitionenhancing drugs that are thought to work by potentiating glutamatergic synaptic efficacy fall into two categories, the pyrrolidinones aniracetam, piracetam, and the related compound 1-BCP

Received June 24, 1996; revised July 30, 1996; accepted Aug. 6, 1996.

We thank Dr. Peter Seeburg for CMV expression plasmids encoding wild-type GluRA $_{i}$, GluRA, and GFP; Dr. Stefano Vicini for technical advice; Dr. Robert Wenthold for GluR1 antibodies; Dr. Zhaolan Lin for advice with structural modeling; Dr. Patrick O’Hara for providing model coordinates; and Dr. Morris Benveniste for scientific discussions. Cyclothiazide was a gift from Lilly Research Laboratories (Indianapolis, IN), and aniracetam was a gift from Hoffmann-La Roche (Basel, Switzerland).

Correspondence should be addressed to Dr. Mark L. Mayer, LCMN/NICHD/ National Institutes of Health, Building 49/Room 5A78, 49 Convent Drive MSC 4495, Bethesda, MD 20892-4495.

Dr. Partin's present address: Department of Anatomy and Neurobiology, Colorado State University, Fort Collins, CO 80523-1670.

${ }^{\text {a }}$ These authors contributed equally to this work.

Copyright (C) 1996 Society for Neuroscience $0270-6474 / 96 / 166634-14 \$ 05.00 / 0$
(Isaacson and Nicoll, 1991; Tang et al., 1991; Vyklicky et al., 1991; Hestrin, 1992; Gouliaev and Senning, 1994; Staubli et al., 1994b) and the benzothiadiazines cyclothiazide, diazoxide, and IDRA21 (Yamada and Rothman, 1992; Bertolino et al., 1993; Patneau et al., 1993; Yamada and Tang, 1993). Both categories of drug slow the rate of AMPA receptor deactivation and desensitization (Isaacson and Nicoll, 1991; Vyklicky et al., 1991; Hestrin, 1992; Patneau et al., 1993; Barbour et al., 1994). Previous work has demonstrated that for AMPA receptors an alternatively spliced exon termed the flip/flop domain (Sommer et al., 1990), which forms part of the extracellular M3-M4 loop (Hollmann et al., 1994; Stern-Bach et al., 1994; Bennett and Dingledine, 1995), regulates the kinetics of the onset of and recovery from desensitization as well as AMPA receptor sensitivity to cyclothiazide and aniracetam (Sommer et al., 1990; Lomeli et al., 1994; Mosbacher et al., 1994; Partin et al., 1994; Johansen et al., 1995). The findings that RNA splicing and RNA editing of this region are regulated in a cell-specific and developmentally programmed manner (Monyer et al., 1991; Lomeli et al., 1994) suggest that this region plays a critical role for AMPA receptor synaptic function.

The localization of molecular determinants of desensitization to this small (38 amino acid) region of the protein makes the flip/flop domain a good target for mutational analysis. We showed previously that exchange of a single residue at position 750 in GluRA (flip Ser and flop Asn) underlies differential modulation of desensitization by cyclothiazide for AMPA receptor splice variants (Partin et al., 1995). The role of this residue in controlling sensitivity to other allosteric modulators of AMPA receptors has not been addressed. Also unknown is whether the effects of cyclothiazide and aniracetam on deactivation are regulated by alternative splicing. To address these issues, we constructed a series of position 750 mutations substituting amino acids with different side chain moieties. These were compared to wild-type receptors for differences in deactivation, desensitization, and modulation by cyclothiazide, aniracetam, and thiocyanate. Using 
kinetic modeling to simulate experimental findings, we suggest that cyclothiazide and aniracetam act via different mechanisms: that aniracetam modulates desensitization as a consequence of slowing channel closing, whereas cyclothiazide modulates desensitization by stabilizing a nondesensitized agonist-bound closed state.

\section{MATERIALS AND METHODS}

Plasmids and mutagenesis. cDNAs for wild-type GluRA $_{\mathrm{i}}$ (flip) and GluRA $_{\text {o }}$ (flop) in CMV expression vectors were generous gifts of Dr. Peter Seeburg (Heidelberg, Germany). Point mutations were made in pBS/GluRAi by dut-ung- oligonucleotide missense mutagenesis (Bio-Rad Muta-Gene Phagemid In Vitro Mutagenesis Kit, Version 2; Bio-Rad, Hercules, CA) and then shuttled into the CMV expression clone using the BspE1 $\rightarrow$ BspE1 (New England Biolabs, Beverly, MA) fragment of GluRA (nt 1777-2320), after which the sequence of the mutation was confirmed. $\mathrm{S}_{750} \mathrm{~N}, \mathrm{~S}_{750} \mathrm{Q}$, GluRA $\mathrm{i}_{\mathrm{i}}[\mathrm{io}$ ], and GluRA $[\mathrm{oi}]$ were described previously (Partin et al., 1995). All cDNAs were purified through two cesium chloride gradients before transfection.

Cells and transfections. Human embryonic kidney 293 fibroblasts (ATCC CRL 1573) were cultured in DMEM supplemented with $10 \%$ fetal bovine serum and $2 \mathrm{~mm}$ glutamine (Life Technologies, Bethesda, $\mathrm{MD})$. Cells were kept at a low density and passaged only up to passage number 15 (P15). Transfections were performed according to the $\mathrm{CaCl}_{2}$ method of Chen and Okayama (1987), with $10-20 \mu \mathrm{g}$ of total DNA per $35 \mathrm{~mm}$ dish. Transfections with glutamate receptor cDNAs also included 10-20\% CMV-GFP, a plasmid encoding the cDNA for green fluorescent protein (Chalfie et al., 1994) (which was a gift from Dr. Peter Seeburg) into which we introduced a point mutation of $\mathrm{S}_{65} \mathrm{~T}$ (Cubitt et al., 1995) for identification of successfully transfected cells.

Whole-cell recording. Transfected 293 cells were voltage-clamped at a holding potential of $-60 \mathrm{mV}$ using an Axopatch-1C amplifier (Axon Instruments, Foster City, CA), and solutions were applied using a 9-barrel flowpipe, stepper-motor-based perfusion system as described previously (Vyklicky et al., 1990). Thin-walled borosilicilate glass microelectrodes (TW150F, World Precision Instruments, Sarasota, FL) had resistances of $2-5 \mathrm{M} \Omega$ when filled with (in $\mathrm{mM}$ ): $135 \mathrm{CsCl}, 10 \mathrm{CsF}, 10$ HEPES, 5 Cs-BAPTA, $1 \mathrm{MgCl}_{2}$, and $0.5 \mathrm{CaCl}_{2}, \mathrm{pH} 7.2,295 \mathrm{mOsm}$. The series resistance was $<10 \mathrm{M} \Omega$ and compensated by at least $80 \%$; voltageclamp errors were $<5 \mathrm{mV}$ for typical AMPA receptor responses. Responses were filtered at $2 \mathrm{kHz}$ with an 8-pole Bessel filter (Frequency Devices, Haverhill, MA), digitized at $0.25-10 \mathrm{msec} /$ point as required, and stored on a Macintosh IIfx computer using an ITC-16 interface (Instrutech, Great Neck, NY) under control of the data acquisition and analysis program Synapse (Synergistic Research, Silver Spring, MD). Extracellular recording solution contained (in $\mathrm{mM}$ ): $145 \mathrm{NaCl}, 5.4 \mathrm{KCl}, 5$ HEPES, $1 \mathrm{MgCl}_{2}, 1.8 \mathrm{CaCl}_{2}$, and $0.1 \mathrm{mg} / \mathrm{ml}$ phenol red, pH 7.3, 295 mOsm. Cyclothiazide and aniracetam were dissolved in DMSO before dilution with extracellular solution (final DMSO concentration, 0.5 or $1 \%$ ) with DMSO added at equal concentrations to other solutions. For experiments with thiocyanate, $20 \mathrm{~mm} \mathrm{NaCl}$ was replaced with $20 \mathrm{~mm}$ NaSCN. Salts, biochemicals, and amino acids were purchased from Aldrich (Milwaukee, WI), Molecular Probes (Eugene, OR), Sigma (St. Louis, MO), and Tocris Cookson (Bristol, UK).

Outside-out patch recording. Outside-out membrane patches from transfected 293 cells were voltage-clamped at a holding potential of -60 $\mathrm{mV}$ using an Axopatch 200A amplifier (Axon Instruments). Agonist responses were filtered at $10 \mathrm{kHz}$ and digitized at $20-100 \mu \mathrm{sec} /$ point. Solutions were applied with an infusion pump (World Precision Instruments), using a flowpipe constructed from 4-barrel square glass tubing with $0.16 \mathrm{~mm}$ bores and $0.4 \mathrm{~mm}$ outer width (Vitro Dynamics, Rockaway, NJ). Movement was driven by a Piezo translator (P245.30, Physik Instrumente, Waldbronn, Germany), which typically permitted solution exchange times in $<200 \mu \mathrm{sec}$ as determined by measurements of open-tip junction potentials recorded from the upper and lower interfaces after disruption of the patch at the end of every experiment; data were excluded for junction potentials with $20-80 \%$ rise times $>500 \mu \mathrm{sec}$. Normal extracellular solution with or without $10 \mathrm{~mm}$ L-glutamate was driven through the lower bores, and the same solutions plus $100 \mu \mathrm{M}$ cyclothiazide, $5 \mathrm{~mm}$ aniracetam, or $20 \mathrm{~mm} \mathrm{NaSCN}$ were driven through the upper bores. Movement between the upper and lower bores within an experiment was achieved using a vernier micrometer (SM-13, Newport Instruments, Irvine, CA).

Data analysis. The rate of onset of desensitization was estimated in both whole-cell and outside-out patch experiments by fitting the decay of the response in the continuous presence of agonist from $95 \%$ of peak to steady state with a single-exponential function $\left(\tau_{\text {des }}\right)$; where noted we used the sum of two exponentials $\left(\tau_{\mathrm{f}}\right.$ and $\left.\tau_{\mathrm{s}}\right)$. The rate of deactivation was estimated by fitting a single exponential $\left(\tau_{\text {deact }}\right)$ to responses to $1 \mathrm{msec}$ applications of agonist. When there was substantial desensitization during the initial component of responses to $1 \mathrm{msec}$ applications of agonist, the rate of deactivation was estimated from fits to the subsequent fast component of decay that developed after removal of agonist and that varied in amplitude between 90 and $20 \%$ of the peak response. In all cases, deactivation was faster than desensitization, such that there was a clear increase in rate of decay after removal of glutamate, even for responses for which there was substantial $(>50 \%)$ desensitization in response to $1 \mathrm{msec}$ applications of glutamate. Sensitivity to cyclothiazide, aniracetam, and thiocyanate was estimated by comparing desensitization and deactivation time constants in the absence and presence of modulator. Whole-cell responses are shown individually; patch responses are the average of 5-20 successive agonist applications. Data are presented as mean \pm SEM except as noted. When statistical analysis was performed, Student's unpaired one- and two-tailed $t$ tests were used.

Kinetic modeling was performed using FastFlow, a previously described program written by Dr. John Clements (Benveniste et al., 1990). The initial rate constants used for modeling were taken from the three-binding-site model of Raman and Trussell (1995) but were modified to reproduce the properties of recombinant GluRA as determined experimentally. This entailed (1) removing the third agonist-binding step (C3) and two open states $\left(\mathrm{O}_{2}^{\text {slow }}\right.$ and $\left.\mathrm{O}_{3}\right)$, yielding decays that were well fit by single- rather than double-exponential functions, (2) slowing the rates of channel opening and closing by half, and (3) slowing the microscopic rates for onset of desensitization and recovery from desensitization such that the modeled responses desensitized and recovered with time constants similar to those found experimentally for recombinant GluRA. The affinity of glutamate for the desensitized agonist-bound states was adjusted to satisfy microscopic reversibility. The rates for binding of cyclothiazide and aniracetam were modeled based on experimental measurements of the affinities/efficacies of the respective modulator.

Analysis of the structure of GluRA was made using model coordinates for GluR3 provided by Dr. Patrick J. O'Hara (ZymoGenetics, Seattle, WA). The model was visualized using either QUANTA V4.0 (Molecular Simulations, Burlington, MA) or LOOK V2.0 (Molecular Applications Group, Palo Alto, CA). The predicted effects of point mutations were calculated and visualized using an algorithm of LOOK that allows point mutations at a single residue to be generated, identifies the nearest neighbors (within a $5 \AA$ radius) of that residue, and then calculates the predicted conformation of the side chains of the selected residue and the nearest neighbors as a consequence of the mutation. The mutated structure was then overlaid with the nonmutated structure for comparison.

\section{RESULTS}

\section{Position 750 mutations differentially regulate responses to cyclothiazide and aniracetam}

To determine the constraints at position 750 that influence receptor gating and allosteric modulation by cyclothiazide and aniracetam, we mutated the Ser residue at this site in GluRA ${ }_{i}$ to Asn, Ala, Asp, Gly, Gln, Met, Cys, Thr, Leu, Val, and Tyr (Fig. 1A). The resulting cDNAs were expressed as homo-oligomers by transient transfection of 293 cells and assayed by rapid perfusion in the whole-cell configuration. The mutants $S_{750} T, S_{750} L, S_{750} Y$, and $S_{750} V$ did not generate functional responses; $S_{750} C$ and $S_{750} \mathrm{M}$ expressed poorly; $S_{750} D$ gave responses only in the presence of cyclothiazide; and the remaining mutants generated robust responses to glutamate in both the presence and the absence of modulators. Figure $1 B$ shows examples of whole-cell currents evoked by $1 \mathrm{~mm}$ glutamate in the presence of $100 \mu \mathrm{M}$ cyclothiazide for wild-type GluRA $_{\mathrm{i}}, \mathrm{GluRA}_{\mathrm{o}}$, and some of the position 750 substitutions that were found to be functional. The only receptor for which desensitization was essentially blocked was wild-type GluRA $_{\mathrm{i}}$ (Table 1); all of the functional mutants studied continued to show desensitization in the presence of cyclothiazide. The rate of onset of desensitization was slowed most for $\mathrm{S}_{750} \mathrm{~A}\left(\tau_{\mathrm{des}} 1690 \pm\right.$ 
A

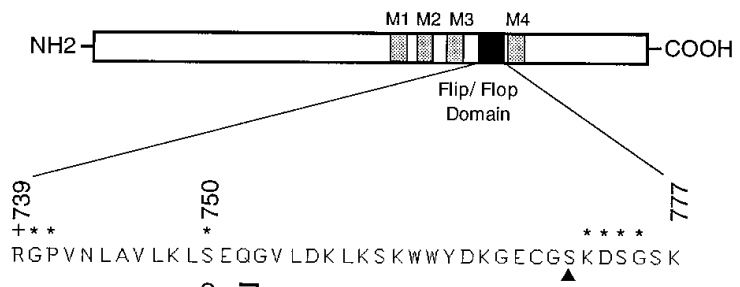

GIURAi RGPVNLAVLKLSEQGVLDKLKSKWWYDKGECGSKDSGSK

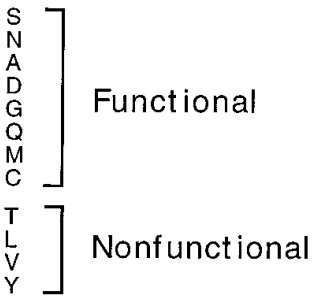

GluRAo RNPVNLAVLKLNEQGLLDKLKNKWWYDKGECGTGGGDSK
B

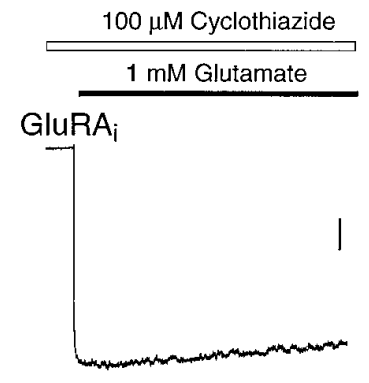

$\mathrm{S}_{750} \mathrm{~N} \tau_{\text {des }} 316 \mathrm{~ms}$

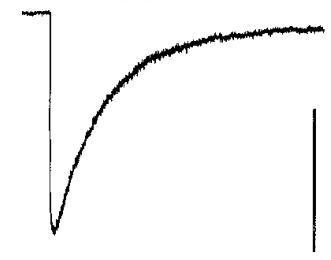

$\mathrm{S}_{750} \mathrm{D} \tau_{\mathrm{s}} 2.45 \mathrm{~s}$

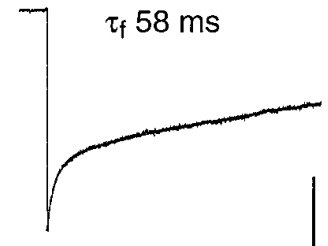

$\mathrm{S}_{750} \mathrm{Q} \tau_{\text {des }} 2.7 \mathrm{~ms}$

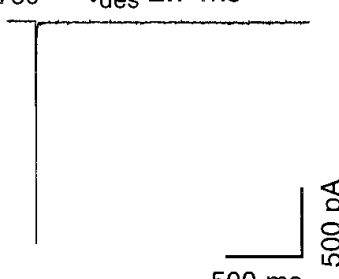

$500 \mathrm{~ms}$

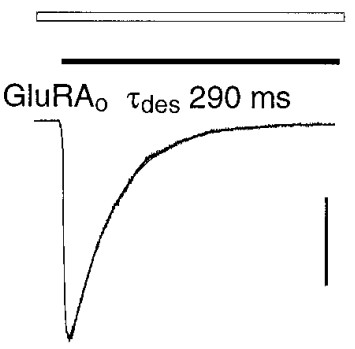

$\mathrm{S}_{750} \mathrm{~A} \tau_{\text {des }} 1.76 \mathrm{~s}$

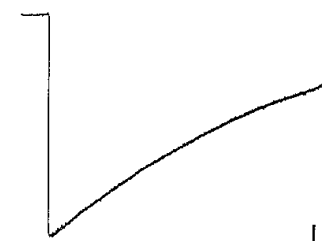

$\mathrm{S}_{750} \mathrm{G} \tau_{\mathrm{des}} 346 \mathrm{~s}$

$\rightarrow$

$\mathrm{S}_{750} \mathrm{M}^{*} \tau_{\text {des }} 3.4 \mathrm{~ms}$

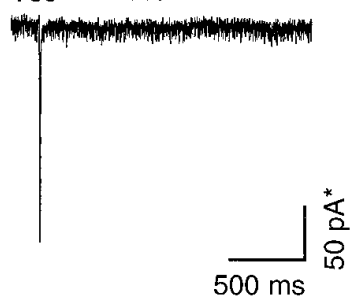

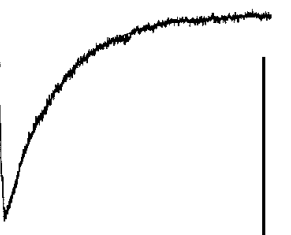

Figure 1. Mutations at GluRA $\mathrm{flip}_{\text {fip }} \operatorname{Ser}_{750}$ and their modulation by cyclothiazide. $A$, Schematic diagram of an AMPA receptor subunit; gray boxes represent membrane domains; a black box represents the flip/flop domain (residues 739-777 of the mature peptide for GluRA). Below is the amino acid sequence of this domain for GluRA $_{\mathrm{i}}$ (top) and GluRA (bottom). The site for RNA editing $(\mathrm{R} / \mathrm{G})$ that occurs in GluRB, $-\mathrm{C}$, and -D is shown by + ; amino acids for which there are conserved differences between the flip and the flop variants of AMPA receptors are marked by *; the point at which the structural homology with LAOBP ends is marked with $\boldsymbol{\Lambda}$. Amino acids listed between the GluRA $A_{i}$ and GluRA $A_{o}$ sequences
149 msec; $n=11$ ). An intermediate response similar to that for wild-type GluRA ${ }_{\mathrm{o}}\left(\tau_{\mathrm{des}} 301 \pm 14 \mathrm{msec} ; n=9\right)$ was observed for $\mathrm{S}_{750} \mathrm{G}\left(\tau_{\text {des }} 332 \pm 45 \mathrm{msec} ; n=6\right)$ and $\mathrm{S}_{750} \mathrm{~N}\left(\tau_{\text {des }} 336 \pm 20 \mathrm{msec}\right.$; $n=12$ ). For $\mathrm{S}_{750} \mathrm{M}, \mathrm{S}_{750} \mathrm{C}$, and $\mathrm{S}_{750} \mathrm{Q}$, the rate of onset of desensitization was rapid $\left(\tau_{\mathrm{des}} 3-6 \mathrm{msec} ; n=2-7\right)$ and not significantly different from control (Table 1$). S_{750} D$ was unusual in that it expressed no current under control conditions, but large currents in the presence of cyclothiazide; the decay in the presence of cyclothiazide was best fit by a double exponential [ $\tau_{\mathrm{f}} 58 \pm$ $\left.5.0 \mathrm{msec}\left(\mathrm{A}_{\mathrm{f}} 38 \pm 3 \%\right) ; \tau_{\mathrm{s}} 2857 \pm 328 \mathrm{msec} ; n=9\right]$. Because of the limited solubility of cyclothiazide in physiological solutions, we were unable to examine the effects of higher concentrations on $\mathrm{S}_{750} \mathrm{D}$ or the other mutants.

As reported previously, aniracetam also shows splice-variant specificity for modulation of desensitization but, in contrast to cyclothiazide, the effect is greater for GluRA ${ }_{o}$ than GluRA (Johansen et al., 1995). To determine the role of position 750 in differential modulation by aniracetam, the desensitization kinetics of the same mutants assayed for modulation by cyclothiazide were analyzed for sensitivity to $5 \mathrm{~mm}$ aniracetam (Fig. 2), a concentration chosen on the basis of previous work on native AMPA receptors and which is at the solubility limit of aniracetam in physiological saline with 1\% DMSO (Isaacson and Nicoll, 1991; Vyklicky et al., 1991). As seen from the overlay of representative traces in Figure $2 B$, aniracetam slowed the onset of desensitization of $\mathrm{S}_{750} \mathrm{~N}\left(\tau_{\mathrm{des}} 31 \pm 3.2 \mathrm{msec} ; n=7\right)$ to a greater extent than for GluRA ${ }_{\mathrm{i}}\left(\tau_{\mathrm{des}} 20 \pm 1.4 \mathrm{msec} ; n=5\right)$; the extent of modulation for $\mathrm{S}_{750} \mathrm{~N}$ was similar to that for GluRA ${ }_{\mathrm{o}}\left(\tau_{\mathrm{des}} 32 \pm 9 \mathrm{msec} ; n=\right.$ 6), suggesting that an Asn residue at position 750 underlies the higher sensitivity of flop splice variants to aniracetam (Johansen et al., 1995). However, the equilibrium current in the presence of aniracetam for $\mathrm{S}_{750} \mathrm{~N}$ was substantially greater (15- \pm 5-fold potentiation of steady-state current) than for GluRA o (2.8- \pm 0.6 -fold) or the other mutations (5- to 10-fold range). A similar observation was made for potentiation of equilibrium currents by cyclothiazide; after a $15 \mathrm{sec}$ application of glutamate in Xenopus oocytes, $\mathrm{S}_{750} \mathrm{~N}$ equilibrium current was potentiated by cyclothiazide 2.5 -fold more than either $\mathrm{S}_{750} \mathrm{~A}$ or $\mathrm{S}_{750} \mathrm{G}$ (data not shown), even though in the present experiments $\tau_{\text {des }}$ in the presence of cyclothiazide was much slower for $S_{750} A$ than for $S_{750} N$ or $S_{750} G$ (Table 1).

Figure 3 plots the change in time constant of onset of desensitization for mutations that were modulated by cyclothiazide and aniracetam versus increasing size of the amino acid side chain at position 750. For both drugs, one residue is clearly preferred; however, the amino acid permitting the most efficacious modulation for cyclothiazide is different than for aniracetam. For both drugs, side chains that are either larger or smaller result in less efficacious modulation. In the case of cyclothiazide, this effect is

were introduced in GluRA $\mathrm{i}_{\mathrm{i}}$ at position 750 and are grouped according to functional criteria. $B$, Whole-cell currents evoked from transiently transfected 293 cells expressing wild-type or mutant receptors. Currents were evoked by a $2 \mathrm{sec}$ application of $1 \mathrm{~mm}$ glutamate after preincubation for $>30 \mathrm{sec}$ with $100 \mu \mathrm{M}$ cyclothiazide. Decays were well fit with a single exponential (superimposed on traces), with the exception of wild-type GluRA $_{i}$, which desensitized too slowly to be fit, and $\mathrm{S}_{750} \mathrm{D}$, which was best fit by a double exponential. Every point mutation studied altered the ability of cyclothiazide to slow the onset of desensitization, as compared to wild-type GluRA ${ }_{\mathrm{i}}$, with $\mathrm{S}_{750} \mathrm{M}$ and $\mathrm{S}_{750} \mathrm{Q}$ permitting little and no modulation, respectively. Calibration bars represent $500 \mathrm{msec}$ and $500 \mathrm{pA}$, except for $\mathrm{S}_{750} \mathrm{M}$, for which the current bar represents $50 \mathrm{pA}$. 


\begin{tabular}{|c|c|c|c|c|c|c|c|c|c|}
\hline & GluRA $_{i}$ & GluRA $_{\circ}$ & $\mathrm{S}_{750} \mathrm{~A}$ & $\mathrm{~S}_{750} \mathrm{C}$ & $\mathrm{S}_{750} \mathrm{D}$ & $\mathrm{S}_{750} \mathrm{G}$ & $\mathrm{S}_{750} \mathrm{M}$ & $\mathrm{S}_{750} \mathrm{~N}$ & $\mathrm{~S}_{750} \mathrm{Q}$ \\
\hline $\begin{array}{l}\text { Control } \tau_{\text {des }} \\
\quad(1 \mathrm{~mm} \mathrm{Glu})\end{array}$ & $\begin{array}{l}6.0 \pm 0.4 \\
\quad(n=11)\end{array}$ & $\begin{array}{l}6.7 \pm 0.4 \\
\quad(n=11)\end{array}$ & $\begin{array}{r}7.2 \pm 0.02 \\
(n=11)\end{array}$ & $\begin{array}{l}5.2 \pm 0.5 \\
\quad(n=3)\end{array}$ & $\begin{array}{l}\text { No response } \\
\quad(n=12)\end{array}$ & $\begin{array}{l}5.9 \pm 0.5 \\
\quad(n=7)\end{array}$ & $\begin{array}{l}3.0 \pm 0.3 \\
\quad(n=15)\end{array}$ & $\begin{array}{l}5.9 \pm 0.5 \\
\quad(n=14)\end{array}$ & $\begin{array}{l}3.8 \pm 0.4 \\
\quad(n=10)\end{array}$ \\
\hline $\begin{array}{l}\text { Cyclo } \tau_{\mathrm{des}}{ }^{a} \\
(1 \mathrm{~mm} \text { Glu })\end{array}$ & $\begin{array}{l}\text { Nondesensitizing } \\
\quad(n=10)\end{array}$ & $\begin{array}{r}301 \pm 14 \\
\quad(n=9)\end{array}$ & $\begin{array}{r}1690 \pm 149 \\
(n=11)\end{array}$ & $\begin{array}{l}4.2 \\
\quad(n=2)\end{array}$ & $\begin{array}{l}\tau_{\mathrm{f}}=58 \pm 5.0 \\
\tau_{\mathrm{s}}=2857 \pm 328 \\
\mathrm{amp}_{\mathrm{f}}=38 \pm 3 \% \\
\quad(n=9)\end{array}$ & $\begin{array}{l}332 \pm 45 \\
\quad(n=6)\end{array}$ & $\begin{array}{l}4.7 \pm 1.8 \\
\quad(n=4)\end{array}$ & $\begin{array}{l}336 \pm 20 \\
\quad(n=12)\end{array}$ & $\begin{array}{l}4.1 \pm 0.7 \\
\quad(n=7)\end{array}$ \\
\hline $\begin{array}{l}\text { Ani } \tau_{\mathrm{des}}^{b} \\
\quad(1 \mathrm{~mm} \text { Glu })\end{array}$ & $\begin{array}{l}20 \pm 1.4 \\
\quad(n=5)\end{array}$ & $\begin{array}{l}32 \pm 2.9 \\
\quad(n=6)\end{array}$ & $\begin{array}{r}16 \pm 0.1 \\
(n=5)\end{array}$ & $\begin{array}{l}5.3 \pm 0.6 \\
\quad(n=3)\end{array}$ & $\begin{array}{l}\text { No response } \\
\quad(n=6)\end{array}$ & $\begin{array}{l}13 \pm 1.5 \\
\quad(n=7)\end{array}$ & $\begin{array}{l}5.2 \pm 0.9 \\
\quad(n=10)\end{array}$ & $\begin{array}{l}31 \pm 3.2 \\
\quad(n=7)\end{array}$ & $\begin{array}{l}7.0 \pm 0.8 \\
\quad(n=10)\end{array}$ \\
\hline $\begin{array}{l}\text { Control } \tau_{\mathrm{des}} \\
(0.5 \mathrm{~mm} \text { AMPA })\end{array}$ & $\begin{array}{l}7.2 \pm 0.5 \\
\quad(n=24)\end{array}$ & $\begin{array}{r}7.4 \pm 0.6 \\
\quad(n=6)\end{array}$ & $\begin{array}{r}11.4 \pm 1.3 \\
(n=13)\end{array}$ & - & - & - & - & $\begin{array}{l}7.6 \pm 0.9 \\
\quad(n=15)\end{array}$ & $\begin{array}{l}6.1 \pm 0.6 \\
\quad(n=12)\end{array}$ \\
\hline $\begin{array}{l}\mathrm{SCN} \tau_{\mathrm{des}}^{c} \\
\quad(0.5 \mathrm{~mm} \text { AMPA })\end{array}$ & $\begin{array}{l}5.1 \pm 0.3 \\
\quad(n=24)\end{array}$ & $\begin{array}{l}8.3 \pm 0.5 \\
\quad(n=6)\end{array}$ & $\begin{aligned} 7.7 & \pm 0.9 \\
(n & =13)\end{aligned}$ & - & - & - & - & $\begin{array}{l}7.9 \pm 1 \\
\quad(n=15)\end{array}$ & $\begin{array}{l}4.4 \pm 0.5 \\
\quad(n=12)\end{array}$ \\
\hline
\end{tabular}

Time constants are given in msec as mean \pm SEM.

${ }^{a} 100 \mu \mathrm{M}$ cyclothiazide.

${ }^{b} 5 \mathrm{~mm}$ aniracetam.

${ }^{c} 20 \mathrm{~mm}$ thiocyanate.

extreme, and although cyclothiazide is much more efficacious than aniracetam it is only $\operatorname{Ser}_{750}$ for which cyclothiazide essentially blocks desensitization. For aniracetam, mutants with a broader range of side chains show modulation of desensitization (compare modulation by aniracetam but not by cyclothiazide of $\mathrm{S}_{750} \mathrm{M}$ and $\mathrm{S}_{750} \mathrm{Q}$ ), yet the difference in efficacy of aniracetam between the most and least sensitive mutants is less than fourfold. An interesting exception to this is $S_{750} \mathrm{D}$, which is strongly modulated by cyclothiazide yet insensitive to aniracetam. $\mathrm{S}_{750} \mathrm{D}$ also shows no control response in the absence of modulators, although when expressed in oocytes there was a small (1-2 nA) equilibrium current in response to glutamate (data not shown). The relative differences in side chain sensitivity and efficacy for modulation by aniracetam and cyclothiazide for position 750 mutants could arise through a number of mechanisms including changes in the structure of a single binding pocket that differentially affects the two drugs, or modulation via different mechanisms, one of which limits the efficacy of modulation by aniracetam but not cyclothiazide.

The mutants $S_{750} T, S_{750} L, S_{750} Y$, and $S_{750} V$ generated nonfunctional receptors. This could arise from a variety of causes: gross misfolding of the protein, inappropriate intermolecular contacts such that the subunits cannot associate to form homooligomers and subsequently fail to reach the plasma membrane, or inappropriate intramolecular packing resulting in localized deformation of the helix-turn-helix motif that is thought to exist in this region of the flip/flop module (O'Hara et al., 1993; SternBach et al., 1994). To test for appropriate folding and assembly, we performed immunofluorescence experiments, staining both live and permeabilized transfected 293 cells with anti-peptide antisera raised against the N-terminal domain of GluR1 (R. Wenthold, unpublished observations). We found that the level of immunoreactivity for the nonfunctional mutant receptors $S_{750} L$ and $\mathrm{S}_{750} \mathrm{~V}$ and their cellular localization in the plasma membrane of live cells were indistinguishable from that for wild-type GluRA (data not shown), suggesting that these mutant proteins were correctly folded, assembled, and inserted in the plasma membrane. In contrast, although the intracellular level of $\mathrm{S}_{750} \mathrm{~T}$ immunoreactivity was similar to wild-type, little or no immunoreactivity could be detected on the plasma membrane of live cells.

To predict the effect of the mutations on intramolecular pack- ing, we analyzed the predicted structure of the mutations using the LOOK modeling program (see Materials and Methods). Substitutions at position 750 were introduced into a model of GluR3 developed by O'Hara and colleagues (Stern-Bach et al., 1994) based on homology of glutamate receptors with bacterial periplasmic amino acid-binding proteins (O'Hara et al., 1993; Kuryatov et al., 1994; Stern-Bach et al., 1994). The predicted perturbations of local structure as a consequence of mutations that disrupted modulation by cyclothiazide $\left(\mathrm{S}_{750} \mathrm{Q}\right)$ or resulted in a nonfunctional receptor $\left(\mathrm{S}_{750} \mathrm{~L}\right)$ were both minimal. This suggests that position 750 mutations that result in nonfunctional receptors either disrupt contacts in the flip/flop region that are beyond the region of homology of AMPA receptor subunits with bacterial periplasmic amino acid-binding proteins or disrupt intermolecular contacts with a neighboring subunit.

\section{Mutations at Ser $_{750}$ alter control kinetics of deactivation and desensitization}

Whole-cell recordings with position 750 mutants suggest that $\mathrm{S}_{750} \mathrm{Q}$ desensitized slightly faster and that $\mathrm{S}_{750} \mathrm{~A}$ desensitized slower than the other receptors tested (Table 1). Observations of altered desensitization kinetics raised the possibility that deactivation kinetics could also differ, but the whole-cell recording technique lacks sufficient resolution for this determination. Therefore, deactivation kinetics were measured for GluRA, GluRA $_{\mathrm{o}}$, $\mathrm{S}_{750} \mathrm{~N}, \mathrm{~S}_{750} \mathrm{Q}$, and $\mathrm{S}_{750} \mathrm{~A}$ with $1 \mathrm{msec}$ applications of $10 \mathrm{~mm}$ glutamate to outside-out patches. The subunits that were chosen for further study represent naturally occurring isoforms $\left(\right.$ GluRA $_{\mathrm{i}}$ and GluRA $A_{o}$ ), express a critical determinant of differential modulation by aniracetam and cyclothiazide $\left(\mathrm{S}_{750} \mathrm{~N}\right)$, or exhibit altered desensitization kinetics $\left(S_{750} A\right.$ and $\left.S_{750} Q\right)$. Outside-out patch responses of wild-type and mutant GluRA subunits revealed rapid kinetics, with onset of desensitization even during a $1 \mathrm{msec}$ application of glutamate, such that for different subunits the start of deactivation was fit well only for the later phase of the response, beginning from between 95 and $20 \%$ of the peak response. The deactivation kinetics of $\mathrm{S}_{750} \mathrm{~A}\left(\tau_{\text {deact }} 0.97 \pm 0.06 \mathrm{msec} ; n=21\right)$ were slower $\left(p<0.01\right.$ vs GluRA $\left.{ }_{i}\right)$, and those for $\mathrm{S}_{750} \mathrm{Q}\left(\tau_{\text {deact }}\right.$ $0.68 \pm 0.03$ msec; $n=17)$ were faster $\left(p<0.05\right.$ vs GluRA $\left._{i}\right)$ than other subunits tested (Fig. $4 A, B)$. Similarly, $\mathrm{S}_{750} \mathrm{~A}\left(\tau_{\mathrm{des}} 3.95 \pm\right.$ 0.17 msec; $n=22$ ) desensitized significantly more slowly $(p<$ 

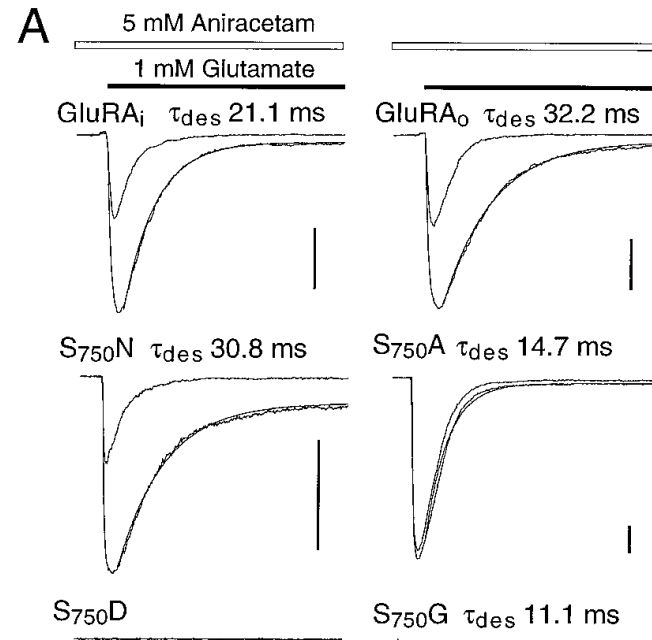

$\mathrm{S}_{750} \mathrm{~A} \tau_{\text {des }} 14.7 \mathrm{~ms}$
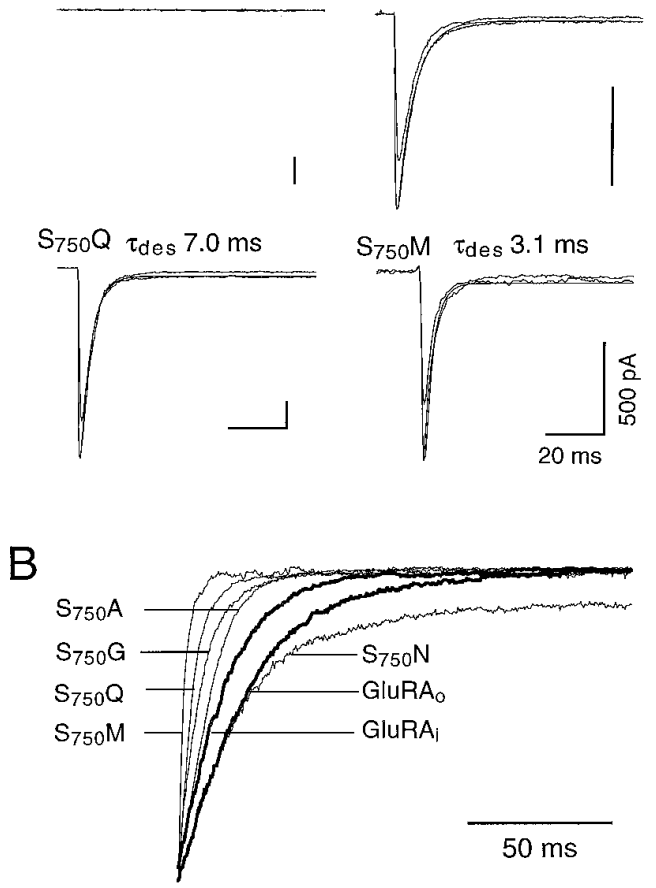

Figure 2. Aniracetam modulation of GluRA $\mathrm{o}_{\mathrm{o}}$ is directed by the ASN residue at position 750. $A$, Superimposed whole-cell responses to $0.5 \mathrm{sec}$ applications of $1 \mathrm{~mm}$ glutamate recorded before and after preincubation for $>30 \mathrm{sec}$ with $5 \mathrm{~mm}$ aniracetam. Single-exponential fits are superimposed on responses recorded in the presence of aniracetam, which slowed the onset of desensitization for GluRA $\mathrm{o}_{\mathrm{o}}$ to a greater extent than GluRA . The point mutation $\mathrm{S}_{750} \mathrm{~N}$ was sufficient to change flip-like modulation to flop-like modulation. Neither a control current nor a current in the presence of aniracetam could be recorded for $\mathrm{S}_{750}$ D. B, Superimposition of the traces shown above and recorded in the presence of aniracetam, normalized to their peak amplitude, demonstrate that no other point mutation permits better modulation by aniracetam than $\mathrm{S}_{750} \mathrm{~N}$. Traces for wild-type GluRA ${ }_{i}$ and GluRA ${ }_{o}$ are shown in bold for comparison.

$0.001)$ and $\mathrm{S}_{750} \mathrm{Q}\left(\tau_{\mathrm{des}} 1.59 \pm 0.04 \mathrm{msec} ; n=16\right)$ desensitized more rapidly $(p<0.001)$ than wild-type GluRA $\mathrm{i}_{\mathrm{i}}$. There were no significant differences between GluRA $A_{i}$ and GluRA $A_{o}$ in deactivation kinetics (Fig. $4 C$ ), although there was a statistically significant difference $(p<0.001)$ in desensitization kinetics: GluRA $\tau_{\mathrm{ides}}$ $2.45 \pm 0.1 \mathrm{msec}(n=28) ;$ GluRA $_{\mathrm{o}} \tau_{\mathrm{des}} 3.23 \pm 0.1 \mathrm{msec}(n=32$; Fig. $4 D)$. The deactivation kinetics of wild-type GluRA $\left(\tau_{\text {deact }}\right.$ $0.79 \pm 0.04 ; n=28$ ) are much faster than those of AMPA receptors in hippocampal neurons (Vyklicky et al., 1991;
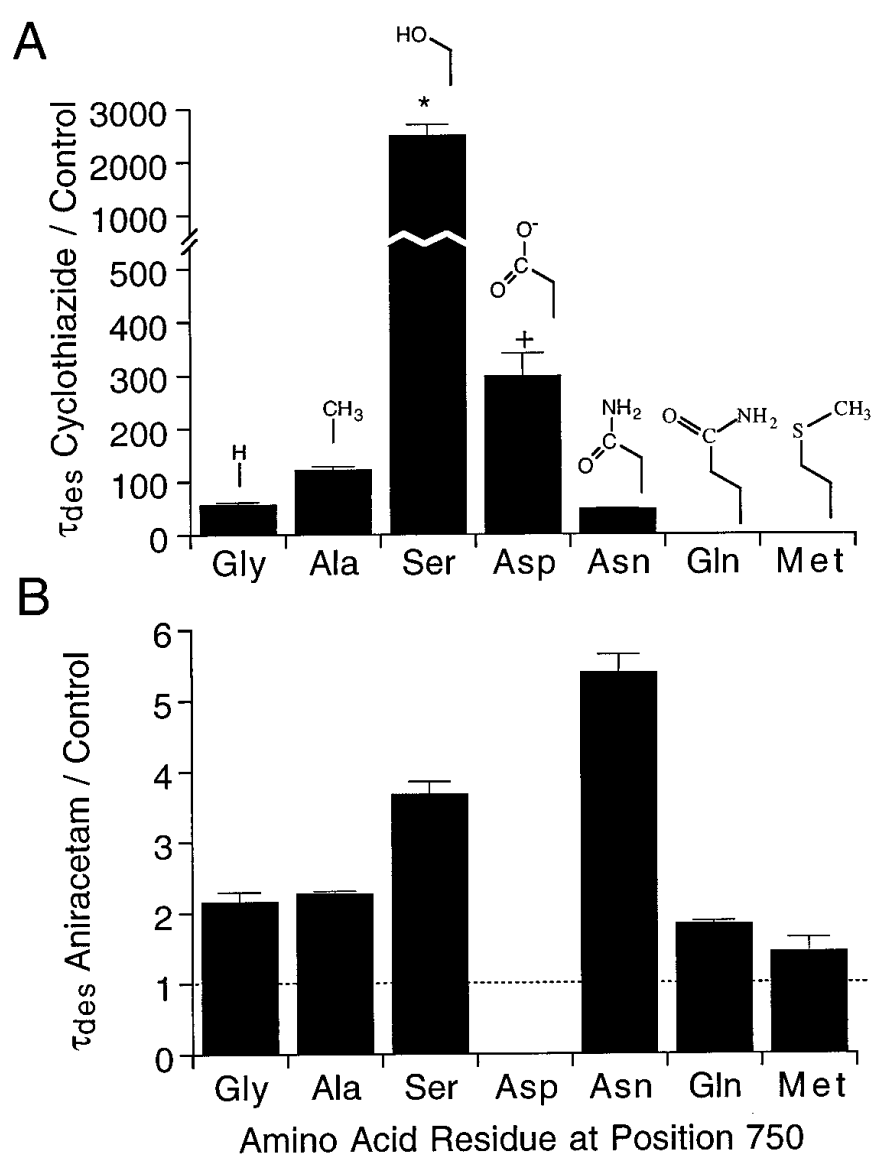

Figure 3. Comparison of the ability of cyclothiazide and aniracetam to modulate desensitization for GluRA $\mathrm{i}_{\mathrm{i}}$ and position 750 point mutants. $A$, Bar plot showing the effect of position 750 point mutants on modulation by cyclothiazide ( $\tau_{\text {des }}$ cyclothiazide $/ \tau_{\text {des }}$ control); mutants are displayed in increasing order of size with the structures of corresponding amino acid side chains shown above the bars. The asterisk denotes that the decay for wild-type GluRA $_{\mathrm{i}}(\mathrm{Ser})$ was estimated from studies on the dissociation kinetics of cyclothiazide in the presence of glutamate (see Fig. 8). The plus sign $(+)$ indicates that the value for $\mathrm{S}_{750} \mathrm{D}$ is an average of the fast and slow components weighted by their relative amplitudes. $B$, Bar plot showing the effect of position 750 point mutants on modulation by aniracetam $\left(\tau_{\text {des }}\right.$ aniracetam $/ \tau_{\text {des }}$ control $) . \mathrm{S}_{750} \mathrm{D}$ expressed neither a control response nor any response in the presence of aniracetam. Comparison of $A$ and $B$ reveals no correlation between modulation by cyclothiazide and aniracetam, suggesting that the molecular determinants governing allosteric modulation of desensitization differs for these ligands. The plots summarize data from whole-cell experiments performed on transfected 293 cells (see Figs. 1, 2)

Colquhoun et al., 1992), are reminiscent of the fast kinetics found for AMPA receptors in nMAG neurons (Raman and Trussell, 1995), and are only slightly slower than reported for homomeric GluRD (Mosbacher et al., 1994).

It had been reported that RNA editing of the Arg/Gly site in the $\mathrm{N}$ terminus of the flip/flop domain results in a change in the time constant $\left(\tau_{\text {rec }}\right)$ for recovery from desensitization (Lomeli et al., 1994). However, the intronic sequences necessary for RNA editing at this site are not found in the GluRA gene and, therefore, RNA editing of GluRA is not found in vivo. To verify that point mutations at position 750 did not affect recovery from desensitization, we measured $\tau_{\text {rec }}$ for GluRA $_{\mathrm{i}}$, GluRA $_{\mathrm{o}}$, and three of the point mutations (Fig. 4E,F) and found that they had indistinguishable time constants for recovery from desensitization (mean $\tau_{\text {rec }} 147 \pm 3$ msec; $n=5-8$ ). Surprisingly, this value is substantially slower than reported previously for 

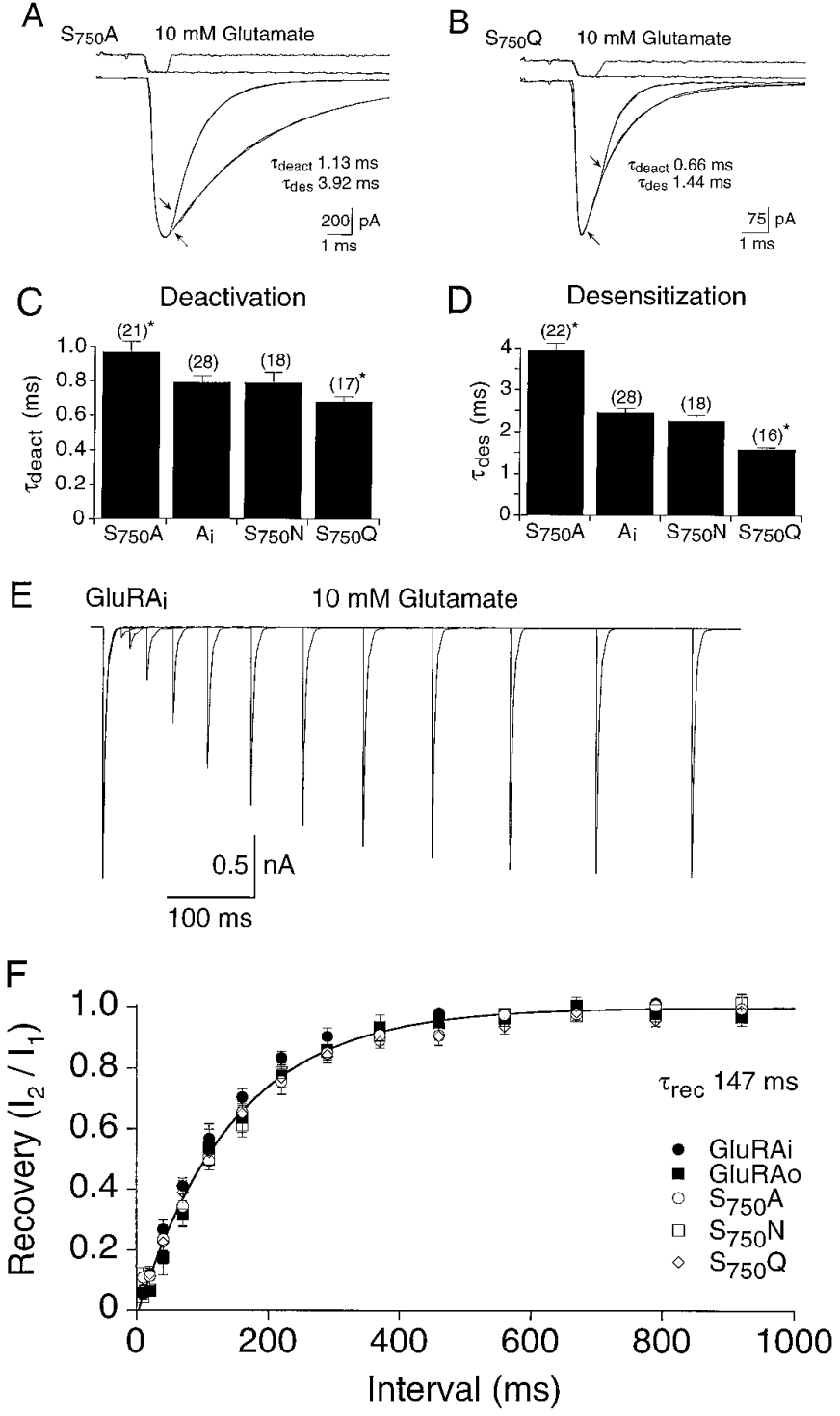

Figure 4. Deactivation and desensitization kinetics for control responses to glutamate in outside-out patches. $A$, Responses for $\mathrm{S}_{750} \mathrm{~A}$, evoked by $1 \mathrm{msec}$ (deactivation) or $100 \mathrm{msec}$ (desensitization) applications of $10 \mathrm{~mm}$ glutamate. $B$, Similar responses for $\mathrm{S}_{750} \mathrm{Q}$. Shown above the current traces in $A$ and $B$ are open tip junction currents recorded after the patch was blown off. Time constants for deactivation were estimated from single-exponential fits starting from $\sim 90$ to $60 \%$ of the peak amplitude (arrows); time constants for desensitization were estimated from a single-exponential fit from $95 \%$ of peak. $C$, Bar plot of the time constants of deactivation (mean \pm SEM) as determined from $1 \mathrm{msec}$ application of $10 \mathrm{~mm}$ glutamate. Asterisks above the bars indicate that $\mathrm{S}_{750} \mathrm{~A}$ deactivated significantly more slowly $(p<0.01)$ and $\mathrm{S}_{750} \mathrm{Q}$ deac-

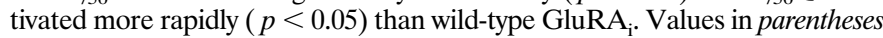
represent the number of patches analyzed. $D$, Bar plot of the time constants of desensitization (mean \pm SEM) as determined from 20-100 msec applications of $10 \mathrm{~mm}$ glutamate. Asterisks above the bars indicate that $\mathrm{S}_{750} \mathrm{~A}$ desensitized significantly more slowly $(p<0.001)$ and $\mathrm{S}_{750} \mathrm{Q}$ desensitized more rapidly $(p<0.001)$ than GluRA . $_{i} E$, Traces from a paired-pulse protocol used to determine the kinetics of recovery from desensitization for wild-type GluRA $\mathrm{i}_{\mathrm{i}}$. Shown are 12 overlaid traces, each consisting of a $10 \mathrm{msec}$ conditioning pulse of $10 \mathrm{~mm}$ glutamate followed by test pulses at intervals of $10-670 \mathrm{msec}$. Traces are normalized to correct for rundown $(<6 \%$ in the example shown). $F$, The ratio of the peak amplitude of the test response to the conditioning response $\left(I_{2} / I_{1}\right.$, mean \pm SEM) plotted versus interpulse interval for GluRA , GluRA $_{\mathrm{o}}$, and three point mutants were well fit with an exponential function, $1-\left[\exp \left(-\mathrm{t} / \tau_{\mathrm{rec}}\right)\right]$, of time constant $147 \mathrm{msec}$. There was no significant difference for $\tau_{\text {rec }}$ among the five receptors studied.

\section{A $100 \mu \mathrm{M}$ Cyclothiazide}

B $5 \mathrm{mM}$ Aniracetam
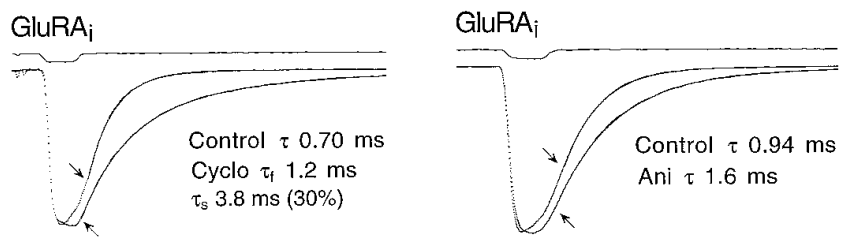

GluRA。
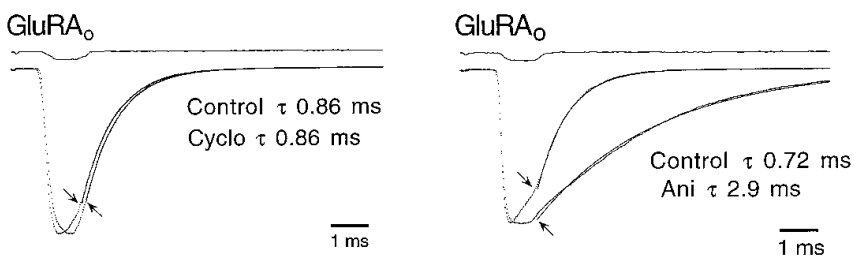

Figure 5. Differential modulation of deactivation by cyclothiazide and aniracetam for wild-type GluRA $\mathrm{i}_{\mathrm{i}}$ and GluRA.$A$, Responses of outsideout patches to $1 \mathrm{msec}$ applications of $10 \mathrm{~mm}$ glutamate, in the absence or presence of $100 \mu \mathrm{M}$ cyclothiazide; responses are normalized to their peak amplitudes to compare their time courses. Open tip junction potentials are shown above each set of responses. Arrows denote the start of singleexponential fits for analysis of deactivation. Cyclothiazide slowed deactivation of GluRA $\mathrm{i}_{\mathrm{i}}$ but failed to modulate deactivation of $\mathrm{GluRA}_{\mathrm{o}} . B$, Aniracetam (5 mM) slowed deactivation more effectively for GluRA $A_{o}$ than GluRA .

homo-oligomeric AMPA receptors assembled from GluRC or GluRD (Lomeli et al., 1994). Technical reasons for this difference were eliminated by measuring $\tau_{\text {rec }}$ for hetero-oligomeric AMPA receptors generated by assembly of GluRA ${ }_{i}$ with GluRB $_{i}$, which gave $\tau_{\text {rec }} 71 \pm 5 \mathrm{msec}(n=5)$, similar to previously published values (Lomeli et al., 1994).

\section{Cyclothiazide and aniracetam selectively modulate deactivation of AMPA receptor splice isoforms}

Both cyclothiazide and aniracetam modulate deactivation of native AMPA receptors (Hestrin, 1992; Patneau et al., 1993; Barbour et al., 1994). Because AMPA receptor splice variants show different sensitivity to these drugs, we examined whether modulation of deactivation is also sensitive to alternative splicing and whether there is a correlation between modulation of deactivation and modulation of desensitization. We looked first at the effects of cyclothiazide and aniracetam on deactivation of wild-type GluRA

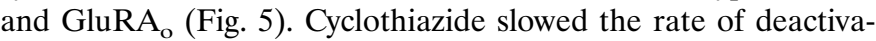
tion of GluRA $A_{i}$ by $2.40- \pm 0.27$-fold $(n=8)$, but did not modulate deactivation of GluRA $(n=11)$. Surprisingly, in view of the much weaker effects of aniracetam on desensitization, we found that deactivation for GluRA ${ }_{\mathrm{o}}$ was slowed 4.09- \pm 0.24 -fold $(n=5)$ by aniracetam even though cyclothiazide failed to modulate deactivation for this splice variant. For GluRA $\mathrm{i}_{\mathrm{i}}$ aniracetam produced a $2.23- \pm 0.19$-fold $(n=6)$ slowing of deactivation similar to the effect of cyclothiazide. We concluded that both compounds differentially modulate deactivation as well as desensitization; for cyclothiazide the effects were greater for GluRA $A_{i}$ than for GluRA $_{o}$, whereas the opposite was true for aniracetam.

We then examined modulation of deactivation for three of the point mutants that showed altered desensitization in the presence of cyclothiazide or aniracetam, $\mathrm{S}_{750} \mathrm{~N}, \mathrm{~S}_{750} \mathrm{~A}$, and $\mathrm{S}_{750} \mathrm{Q}$ (Fig. 6). Modulation of deactivation by cyclothiazide followed the same trend as modulation of desensitization in that clearly a Ser residue at position 750 permits the most efficacious slowing of deactivation (2.40- \pm 0.27 -fold; $n=8$ ); deactivation of $\mathrm{S}_{750} \mathrm{~A}$ was slowed by 1.51- \pm 0.11 -fold $(n=11)$, whereas deactivation of $S_{750} \mathrm{~N}$ and 
A

\section{$100 \mu \mathrm{M}$ Cyclothiazide}

$\underline{S_{750} \mathrm{~A}}$
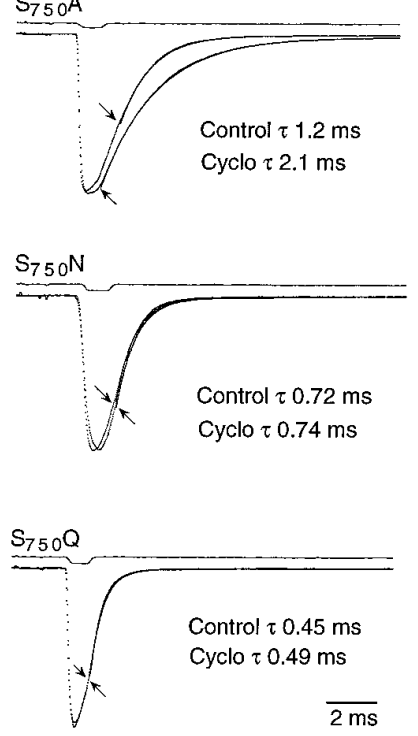

B Deactivation

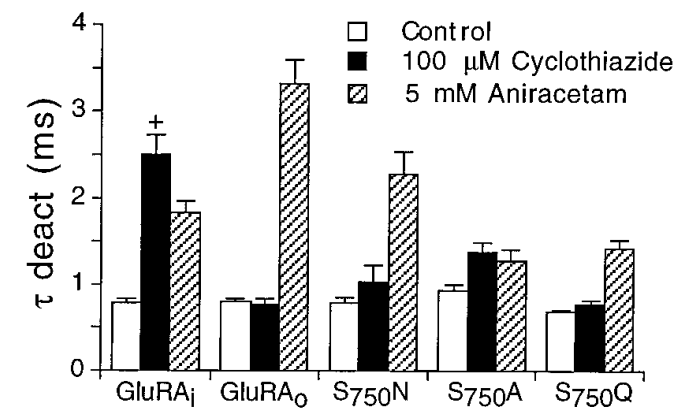

\section{Desensitization}

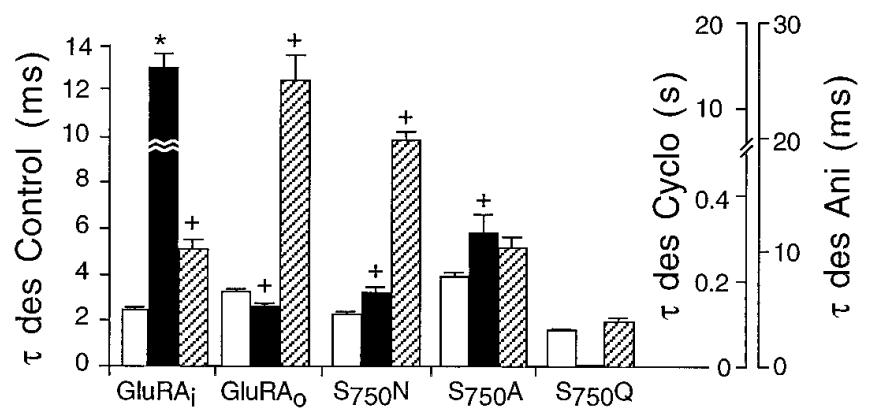

Figure 6. Modulation of deactivation and desensitization for position 750 mutants. $A$, Outside-out patch responses to $1 \mathrm{msec}$ applications of $10 \mathrm{~mm}$ glutamate, in either the absence or the presence of $100 \mu \mathrm{M}$ cyclothiazide; open tip junction potentials are shown above each set of current traces. Arrows denote the start of single-exponential fits for analysis of deactivation. Cyclothiazide slowed deactivation for $S_{750} A$, but not for $S_{750} \mathrm{~N}$ or $\mathrm{S}_{750} \mathrm{Q}$. Responses to $1 \mathrm{msec}$ applications of $10 \mathrm{~mm}$ glutamate in the absence or presence of $5 \mathrm{~mm}$ aniracetam revealed that modulation of deactivation was most efficacious for $\mathrm{S}_{750} \mathrm{~N}$ but also occurred for $\mathrm{S}_{750} \mathrm{Q}$ for which cyclothiazide was inactive. $B$, Bar plots of the time constants for deactivation $\left(\tau_{\text {deact }}\right.$, mean \pm SEM) as determined for controls (open bars), in the presence of $100 \mu \mathrm{M}$ cyclothiazide (solid bars), or in the presence of $5 \mathrm{mM}$ aniracetam (hatched bars) for GluRA ${ }_{\mathrm{i}}, \mathrm{GluRA}_{\mathrm{o}}$, and the three point mutants examined in the outside-out patch configuration. $C$, Bar plots of time constants for desensitization $\left(\tau_{\mathrm{des}}\right.$, mean \pm SEM) for the same
$\mathrm{S}_{750} \mathrm{Q}$ was not affected (Fig. 6B, Table 2). Aniracetam slowed deactivation for $\mathrm{S}_{750} \mathrm{~N}$ (3.41- \pm 0.22 -fold; $\left.n=9\right)$ to a greater extent than the other mutants examined, similar to its greater effect on desensitization for $\mathrm{S}_{750} \mathrm{~N}$ versus $\mathrm{S}_{750} \mathrm{~A}$ and $\mathrm{S}_{750} \mathrm{Q}$ (Fig. $3)$. In general, although there was a clear correlation between the effect of these modulators on desensitization and deactivation kinetics (Fig. 6B,C), this is true qualitatively rather than quantitatively because for $\mathrm{S}_{750} \mathrm{~A}$ desensitization was efficaciously modulated by cyclothiazide (145-fold slowing of the onset of desensitization), whereas deactivation was not (1.52-fold slowing). The kinetics of desensitization measured in outside-out patches were consistently faster (1.1- to 2.9-fold, depending on the subunit and modulator) than those observed by whole-cell recording (Tables $1,2)$. The reasons for this difference are unclear, but most likely reflect slow application of agonist for whole-cell recording and possibly altered channel properties in outside-out patches (Tong and Jahr, 1994).

\section{Thiocyanate modulation of AMPA receptor splice isoforms}

Recent experiments on native and reconstituted AMPA receptors (Bowie and Smart, 1993; Arai et al., 1995; Kessler et al., 1996) have shown that thiocyanate is a modulator of desensitization, but with the opposite effect from that produced by cyclothiazide and aniracetam, because thiocyanate increases the extent and rate of onset of desensitization. To test for differential sensitivity of AMPA receptor splice isoforms to thiocyanate, we first compared whole-cell responses to $500 \mu \mathrm{M}$ AMPA in the presence and absence of $20 \mathrm{~mm}$ thiocyanate (Fig. $7 A$ ) using protocols similar to those for experiments on native receptors expressed in hippocampal slices (Arai et al., 1995), for which the effect of thiocyanate was shown to be greater with AMPA rather than glutamate as agonist. The effect of thiocyanate on GluRA $\mathrm{A}_{\mathrm{i}}$ was similar to that found for native AMPA receptors in hippocampal neurons in that the peak was reduced $17 \pm 3 \%$ and $\tau_{\mathrm{des}}$ accelerated from $7.2 \pm 0.5$ to $5.1 \pm$ $0.3 \mathrm{msec}(n=21)$. The results were different for GluRA ever, in that the peak was consistently increased by $38 \pm 14 \%$, and $\tau_{\text {des }}$ slowed from $7.4 \pm 0.6$ to $8.3 \pm 0.5 \mathrm{msec}(n=6)$. We also tested $\mathrm{S}_{750} \mathrm{Q}$ (resistant to cyclothiazide) and $\mathrm{S}_{750} \mathrm{~N}$ (increased sensitivity to aniracetam) for modulation of desensitization by thiocyanate (Fig. 7A) and found that responses for $\mathrm{S}_{750} \mathrm{~N}$ were similar to those for GluRA ${ }_{o}$, with $\tau_{\text {des }}$ essentially unchanged $(7.6 \pm 0.9$ to $7.9 \pm 1.0 \mathrm{msec} ; n=15)$ but with the peak amplitude potentiated ( $44 \pm 6 \%$ ), whereas for $\mathrm{S}_{750} \mathrm{Q} \tau_{\text {des }}$ accelerated from $6.1 \pm 0.6$ to $4.4 \pm 0.5 \mathrm{msec}(n=12)$ without a significant change in the amplitude of the current $(98 \pm 14 \%)$. Although $\mathrm{S}_{750} \mathrm{~A}$ desensitized almost twice as slowly $\left(\tau_{\text {des }} 11.4 \pm 1.3 ; n=13\right)$ as $\mathrm{S}_{750} \mathrm{Q}(6.1 \pm 0.6 \mathrm{msec} ; n=12)$, thiocyanate accelerated the rate of onset of desensitization $(\sim 33 \%)$ to a similar extent for both mutants (Fig. 7A, Table 1).

To better resolve modulation of desensitization by thiocyanate, as well as to determine whether thiocyanate modulates deactiva-

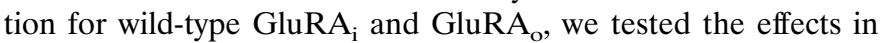
outside-out patches of $20 \mathrm{~mm}$ thiocyanate on responses evoked by

$\leftarrow$

receptors. Note that there are three $y$-axes: one for control responses to 10 $\mathrm{mm}$ glutamate; one for desensitization in the presence of cyclothiazide; and one for desensitization in the presence of aniracetam. Asterisk denotes that, for GluRA, the value represents the time constant of dissociation of cyclothiazide $(15.7 \pm 0.7 \mathrm{sec})$ estimated from experiments shown in Figure $8 D$. Plus signs $(+)$ denote values that include the weighted averages of data fit with two exponentials (see Table 2). 
Table 2. Deactivation and desensitization time constants in outside-out patches

\begin{tabular}{|c|c|c|c|c|c|c|c|}
\hline & GluRA $_{i}$ & GluRA $_{o}$ & $\mathrm{~S}_{750} \mathrm{~A}$ & $\mathrm{~S}_{750} \mathrm{~N}$ & $\mathrm{~S}_{750} \mathrm{Q}$ & GluRAi[io] & GluRAo[oi] \\
\hline$\tau_{\text {deact }}$ control & $\begin{array}{r}0.79 \pm 0.04 \\
(n=28)\end{array}$ & $\begin{array}{r}0.80 \pm 0.04 \\
(n=31)\end{array}$ & $\begin{array}{r}0.97 \pm 0.06 \\
(n=21)\end{array}$ & $\begin{array}{r}0.79 \pm 0.06 \\
(n=18)\end{array}$ & $\begin{array}{c}0.68 \pm 0.03 \\
(n=17)\end{array}$ & $\begin{array}{c}0.81 \pm 0.09 \\
\quad(n=6)\end{array}$ & $\begin{array}{c}0.78 \pm 0.04 \\
\quad(n=6)\end{array}$ \\
\hline$\tau_{\mathrm{des}}$ control & $\begin{array}{r}2.45 \pm 0.10 \\
(n=28)\end{array}$ & $\begin{array}{r}3.23 \pm 0.12 \\
(n=32)\end{array}$ & $\begin{array}{r}3.95 \pm 0.17 \\
(n=22)\end{array}$ & $\begin{array}{r}2.26 \pm 0.14 \\
(n=18)\end{array}$ & $\begin{array}{c}1.59 \pm 0.04 \\
(n=16)\end{array}$ & $\begin{array}{c}2.81 \pm 0.23 \\
\quad(n=6)\end{array}$ & $\begin{array}{r}3.77 \pm 0.2 \\
(n=6)\end{array}$ \\
\hline$\tau_{\text {deact }} 100 \mu \mathrm{M}$ cyclo & $\begin{array}{c}2.10 \pm 0.24^{a} \\
\quad(n=11)\end{array}$ & $\begin{array}{r}0.77 \pm 0.06 \\
\quad(n=15)\end{array}$ & $\begin{array}{r}1.58 \pm 0.13 \\
(n=11)\end{array}$ & $\begin{array}{r}1.03 \pm 0.2 \\
(n=7)\end{array}$ & $\begin{array}{c}0.77 \pm 0.05 \\
(n=11)\end{array}$ & - & - \\
\hline$\tau_{\mathrm{des}} 100 \mu \mathrm{M}$ cyclo & $\begin{array}{l}\text { Nondesensitizing } \\
\quad(n=11)\end{array}$ & $\begin{array}{c}\tau_{\mathrm{f}}=8.5 \pm 0.9 \\
\tau_{\mathrm{s}}=182 \pm 6 \\
\mathrm{amp}_{\mathrm{f}}=23 \pm 2 \% \\
(n=12)\end{array}$ & $\begin{array}{c}\tau_{\mathrm{f}}=6.8 \pm 0.3 \\
\tau_{\mathrm{s}}=579 \pm 45 \\
\mathrm{amp}_{\mathrm{f}}=47 \pm 6 \% \\
(n=10)\end{array}$ & $\begin{array}{c}\tau_{\mathrm{f}}=8.9 \pm 1.10 \\
\tau_{\mathrm{s}}=220 \pm 14 \\
\mathrm{amp}_{\mathrm{f}}=21 \pm 1 \% \\
(n=6)\end{array}$ & $\begin{array}{c}1.78 \pm 0.10 \\
(n=11)\end{array}$ & - & - \\
\hline$\tau_{\text {deact }} 5 \mathrm{mM}$ ani & $\begin{array}{r}1.83 \pm 0.13 \\
(n=10)\end{array}$ & $\begin{array}{r}3.31 \pm 0.28 \\
(n=14)\end{array}$ & $\begin{array}{c}1.23 \pm 0.12 \\
(n=9)\end{array}$ & $\begin{array}{r}2.27 \pm 0.27 \\
(n=10)\end{array}$ & $\begin{array}{c}1.42 \pm 0.10 \\
(n=8)\end{array}$ & $\begin{array}{c}1.94 \pm 0.28 \\
\quad(n=6)\end{array}$ & $\begin{array}{c}2.21 \pm 0.22 \\
\quad(n=5)\end{array}$ \\
\hline$\tau_{\mathrm{des}} 5 \mathrm{mM}$ ani & $\begin{array}{r}10.2 \pm 0.6^{b} \\
(n=10)\end{array}$ & $\begin{array}{r}26.0 \pm 2.3^{c} \\
(n=14)\end{array}$ & $\begin{array}{r}9.38 \pm 0.83 \\
(n=10)\end{array}$ & $\begin{array}{r}27.6 \pm 1.4^{d} \\
(n=10)\end{array}$ & $\begin{array}{c}3.81 \pm 0.11 \\
(n=8)\end{array}$ & $\begin{array}{r}12.3 \pm 1.1 \\
\quad(n=6)\end{array}$ & $\begin{array}{r}26.5 \pm 1.5 \\
(n=5)\end{array}$ \\
\hline
\end{tabular}

Time constants are given in msec as mean \pm SEM.

${ }^{a}$ Includes fast component from $4 / 11$ patches best fit by two exponentials, where the amplitude of the slow component $=32 \pm 5 \%$.

${ }^{b}$ Includes fast component from 3/10 patches best fit by two exponentials, where the amplitude of the slow component $=29 \pm 9 \%$.

${ }^{c}$ Includes slow component from $3 / 14$ patches best fit by two exponentials, where the amplitude of the fast component $=30 \pm 5 \%$.

${ }^{d}$ Includes slow component from $9 / 10$ patches best fit by two exponentials, where the amplitude of the fast component $=40 \pm 4 \%$.

$10 \mathrm{~mm}$ glutamate, which was chosen to allow comparison with the effects of other modulators in outside-out patches (Fig. $7 B$ ). We found a 1.6-fold slowing of $\tau_{\text {deact }}$ for GluRA from $_{0} .69 \pm 0.05$ to $1.12 \pm 0.08 \mathrm{msec}(n=8, p>0.0001)$, whereas for GluRA $\tau_{\text {deact }}$ was not significantly changed $(0.65 \pm 0.04$ to $0.73 \pm 0.04 \mathrm{msec}$; $n=8)$. Thiocyanate had a differential effect on desensitization, accelerating $\tau_{\mathrm{des}}$ for GluRA $(2.17 \pm 0.11$ to $1.58 \pm 0.09 \mathrm{msec})$, but slowing $\tau_{\text {des }}$ for GluRA (from $3.21 \pm 0.27$ to $3.77 \pm 0.29$ msec). Therefore, modulation of deactivation and desensitization by thiocyanate is distinct from modulation by cyclothiazide and aniracetam, but is sensitive to amino acid changes in the flip/flop domain and, specifically, to changes at position 750 .

\section{Kinetic modeling of differential modulation by aniracetam and cyclothiazide}

A variety of kinetic models for ligand-gated ion channels have been developed to describe activation, deactivation, and desensitization. Figure $8 A$ presents a kinetic model for AMPA receptor modulation by aniracetam and cyclothiazide, derived primarily from the work of Vyklicky et al. (1991), Raman and Trussell (1995), and Kessler et al. (1996). The rate constants for the model are given in Table 3 (see also Materials and Methods). The model describes binding of two molecules of agonist leading to a conformational transition to a single open state. In the continued presence of agonist, there is a high probability that the receptor will undergo further transitions to nonconducting, agonist-bound desensitized states $\left(\mathrm{R}_{\mathrm{d}} \mathrm{A}\right.$ and $\left.\mathrm{R}_{\mathrm{d}} \mathrm{A}_{2}\right)$. After channel opening by brief pulses of agonist, a significant fraction of receptors return to the unliganded state without entering the desensitized states $R_{d} A$ and $R_{d} A_{2}$. The model assumes binding of one molecule of modulator and does not address whether aniracetam and cyclothiazide bind to the same site. The model allows desensitization to occur only through closed states, although this assumption has not been proven. Although these simplifications facilitate analysis of modulation, native AMPA receptors are known to have subconductance states (Howe et al., 1991) and, in addition, as modeled by Raman and Trussell (1995), there is evidence for multiple and kinetically distinct open states. Figure $8 B$ shows simulated responses to $10 \mathrm{~mm}$ glutamate generated by the models developed here. These are similar in many ways to experimental responses for GluRA (Figs.
4, 5): there is marked desensitization with a $1 \mathrm{msec}$ pulse of agonist; $\tau_{\text {deact }}(0.85 \mathrm{msec})$ is 3.6 -fold faster than $\tau_{\text {des }}(3.1 \mathrm{msec})$; responses to prolonged application of glutamate desensitize to $<1 \%$ of peak. Modulation by aniracetam similar to that observed for GluRA $A_{o}$ was achieved by slowing the closing rate constant sixfold. This reproduced slowing of deactivation $\left(\tau_{\text {deact }} 5.0 \mathrm{msec}\right)$ and desensitization $\left(\tau_{\mathrm{des}} 16.6 \mathrm{msec}\right)$; for GluRA $\mathrm{o}_{\mathrm{o}}$ the experimentally recorded mean time constants were 3.31 and $26 \mathrm{msec}$, respectively. As would be expected from a cyclic model, slowing the closing rate constant changes accessibility to ligand-bound desensitized states, which results in a slowing of the rate of onset of desensitization (Vyklicky et al., 1991). A similar stabilization of the open state could occur alternatively if modulation by aniracetam resulted from an accelerated rate of channel opening. A kinetic model increasing the opening rate constant 30 -fold did slow deactivation $\left(\tau_{\text {deact }} 3.4 \mathrm{msec}\right)$, but it also slowed desensitization ( $\tau_{\text {des }} 95 \mathrm{msec}$ ) to a much greater extent than observed experimentally, leading us to conclude that modulation of the channel closing rate rather than channel opening was a more probable explanation for the effects of aniracetam. In the model developed here, the channel opening rate constant, $30,000 \mathrm{sec}^{-1}$ in the absence of modulators, would have to be changed to $900,000 \mathrm{sec}^{-1}$ to slow deactivation to the extent seen experimentally. This high rate seems improbable and, indeed, is substantially faster than the maximum opening rate estimated for nicotinic $\left(12,000 \mathrm{sec}^{-1}\right.$; Liu and Dilger, 1991) and $\mathrm{GABA}_{\mathrm{A}}\left(3500 \mathrm{sec}^{-1}\right.$; Jones and Westbrook, 1995) receptor channels. Additional evidence consistent with modulation of the closing rate constant by aniracetam comes from single-channel studies on native receptors for which modulation by aniracetam is observed as an increased mean open time and burst length (Vyklicky et al., 1991). A final prediction of our model is a linear relationship between modulation of deactivation and modulation of desensitization by aniracetam, a correlation confirmed experimentally (see Discussion; Fig. 9).

A kinetic scheme reproducing modulation by cyclothiazide for GluRA $_{\mathrm{i}}$ is shown in Figure $8 A$ (right), but in this case modulation occurs through "stabilization" of an agonist-bound nondesensitized closed state $\left(\mathrm{RMA}_{2}\right)$. This is achieved by increasing agonist affinity for the $\mathrm{RMA}_{2}$ state 20 -fold and slowing the rate of onset 
A Whole Cell
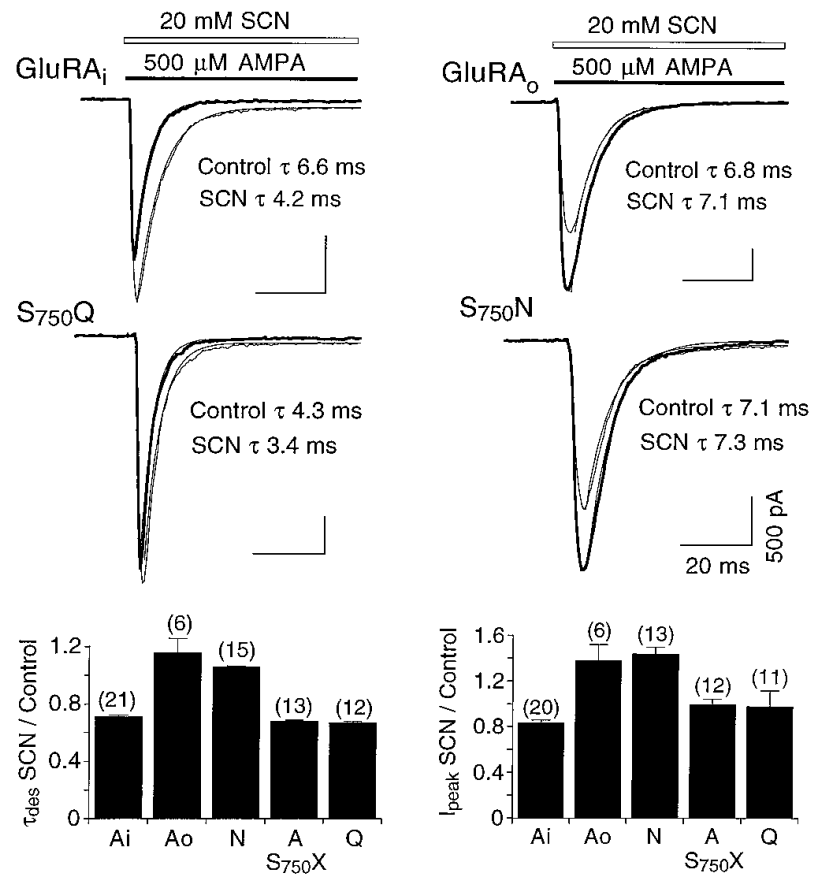

B Outside-Out Patch
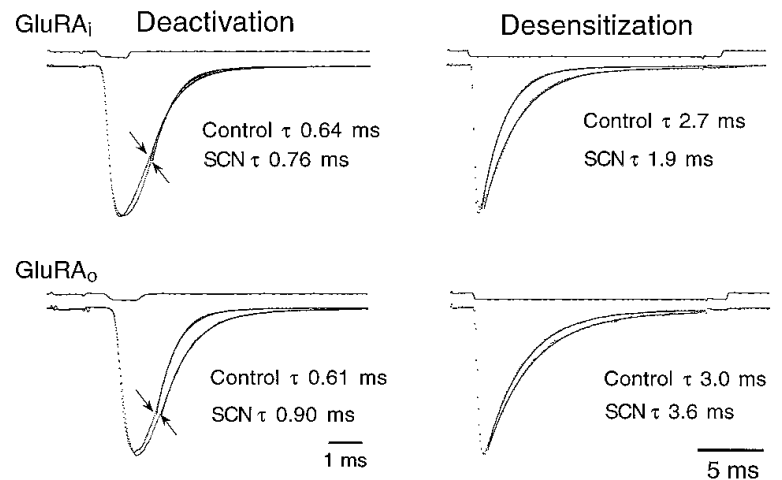

Figure 7. Thiocyanate differentially modulates desensitization of GluRA flip/flop isoforms. $A$, Whole-cell responses to $500 \mu \mathrm{M}$ AMPA in the absence (thin trace) or presence (bold trace) of $20 \mathrm{~mm}$ thiocyanate; singleexponential fits of the indicated time constant are superimposed on the traces. Thiocyanate decreased the peak response and increased the rate of onset of desensitization for GluRA $A_{i}$ and $S_{750} Q$. In contrast, thiocyanate consistently increased the peak amplitude and slowed the onset of desensitization for both GluRA $A_{0}$ and $\mathrm{S}_{750} \mathrm{~N}$. Bar plots summarize the kinetics of onset of desensitization (left) and peak current amplitudes (right) in the presence of thiocyanate plotted relative to control for GluRA , GluRA $_{o}$, and the three point mutants studied $\left(\mathrm{S}_{750} X\right.$, where $X$ represents $\mathrm{N}, \mathrm{A}$, or Q). B, Outside-out patch responses to $10 \mathrm{~mm}$ glutamate in the presence of $20 \mathrm{~mm}$ thiocyanate. Arrows denote the start of single-exponential fits. Open tip junction potentials are shown above the current traces. Deactivation was essentially unchanged for GluRA $A_{i}$ but slowed for GluRA $A_{o}$ in the presence of thiocyanate. The onset of desensitization of $\mathrm{GluRA}_{i}$ was faster in the presence of thiocyanate, whereas thiocyanate slowed the onset of desensitization for GluRA $_{o}$, similar to whole-cell responses recorded using AMPA as agonist.

of desensitization from the $\mathrm{RMA}_{2}$ state 10,000 -fold. Modulation of the onset of desensitization would not account for the slowing of deactivation that is seen experimentally, whereas increasing agonist affinity slows the rate of deactivation by slowing agonist dissociation, but only when the rate of entry into desensitized
A

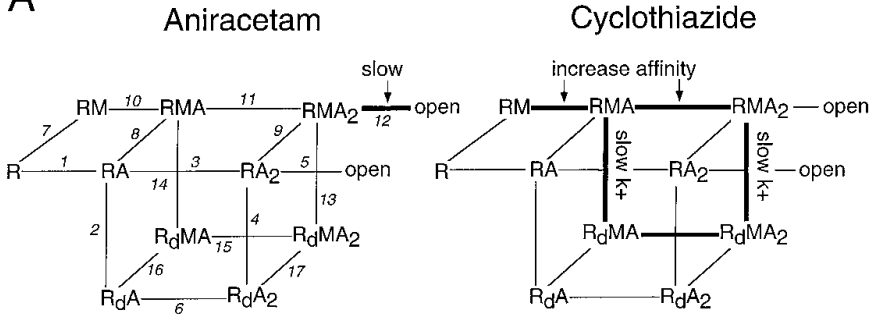

B
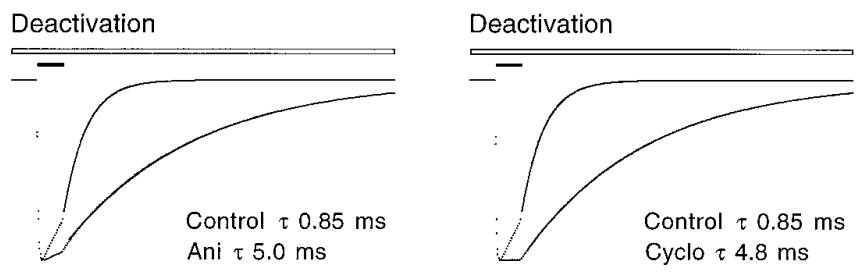

Desensitization
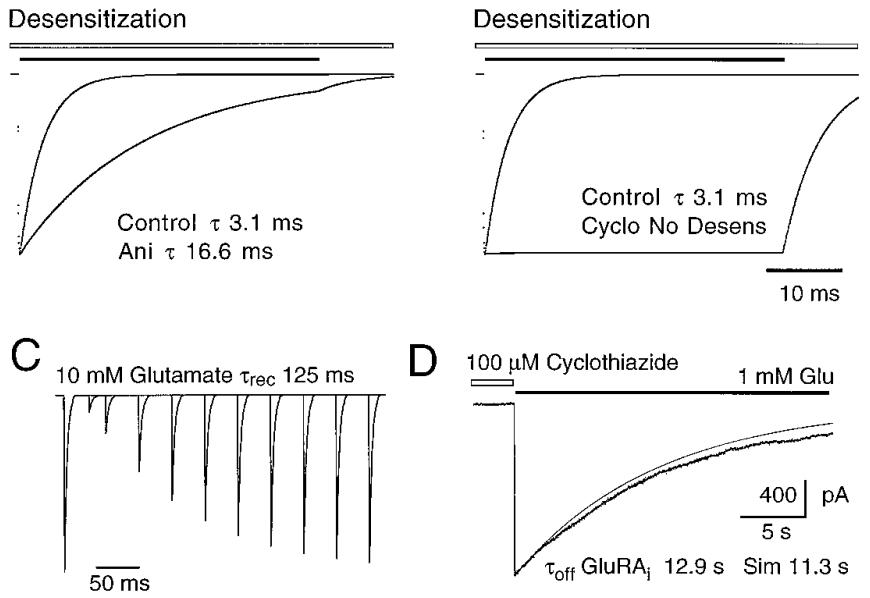

Figure 8. Kinetic modeling suggests different mechanisms for modulation by aniracetam and cyclothiazide. $A$, Cyclic model describing kinetic reactions between states of an AMPA receptor in the presence of either aniracetam (left) or cyclothiazide (right). Bold lines indicate altered rate constants in the presence of aniracetam or cyclothiazide. $R$, Free receptor; $M$, modulator; $A$, agonist (glutamate); $R_{d}$, desensitized state. $B$, Simulated currents representing modulation of deactivation and desensitization by aniracetam (left) or cyclothiazide (right); modulators (open bar) were assumed to be pre-equilibrated with the receptor before application of 10 mM glutamate (closed bar). Responses are normalized to their peak amplitudes to compare their time courses. Modulation of GluRA $\mathrm{mM}$ aniracetam was simulated by slowing only the rate of channel closing sixfold versus control. Modulation of GluRA $\mathrm{i}_{\mathrm{i}}$ by $100 \mu \mathrm{M}$ cyclothiazide was simulated by slowing the rate of onset of desensitization 10,000-fold and increasing the agonist affinity of the cyclothiazide-bound state $\mathrm{RMA}_{2}$ 20 -fold; single-exponential fits are superimposed on the simulated traces. $C$, Simulated recovery from desensitization in the absence of modulator. The data were fit with a single exponential, $\tau_{\text {rec }}=125 \mathrm{msec}$, similar to experimental values. $D$, Decays of a simulated response (thin trace) and an experimentally recorded response of GluRA $A_{i}$ to $1 \mathrm{~mm}$ glutamate in the absence of modulator after preincubation with $100 \mu \mathrm{M}$ cyclothiazide. The rate of decay is assumed to reflect the unbinding of cyclothiazide. For GluRA $_{i}$ the mean dissociation rate was $15.7 \pm 0.7 \mathrm{sec}$; for the simulation it was $11.3 \mathrm{sec}$.

states is reduced. The model predicts very efficacious modulation of desensitization with weaker modulation of deactivation, an effect observed experimentally for cyclothiazide modulation of all GluRA constructs studied. The model also predicts that, different 


\begin{tabular}{|c|c|c|c|c|}
\hline \multirow[b]{2}{*}{ Reaction \# } & \multicolumn{2}{|l|}{ Aniracetam } & \multicolumn{2}{|l|}{ Cyclothiazide } \\
\hline & $k(+) \mathrm{s}-1$ & $k(-) \mathrm{s}-1$ & $k(+) \mathrm{s}-1$ & $k(-) \mathrm{s}-1$ \\
\hline 2 & 1000 & 300 & 1000 & 300 \\
\hline 3 & $10^{7} \mathrm{M}^{-1}$ & 100,000 & $10^{7} \mathrm{M}^{-1}$ & 100,000 \\
\hline 4 & 8000 & 0.2 & 8000 & 0.2 \\
\hline 6 & $10^{7} \mathrm{M}^{-1}$ & 8.3 & $10^{7} \mathrm{M}^{-1}$ & 8.3 \\
\hline 7 & $10^{7} \mathrm{M}^{-1}$ & 5000 & $10^{5} \mathrm{M}^{-1}$ & 0.1 \\
\hline 8 & $10^{7} \mathrm{M}^{-1}$ & 5000 & $10^{5} \mathrm{M}^{-1}$ & 0.01 \\
\hline 9 & $10^{7} \mathrm{M}^{-1}$ & 5000 & $10^{5} \mathrm{M}^{-1}$ & 0.0005 \\
\hline 10 & $2 \times 10^{7} \mathrm{M}^{-1}$ & 300 & $2 \times 10^{7} \mathrm{M}^{-1}$ & $\mathbf{3 0}^{a}$ \\
\hline 11 & $10^{7} \mathrm{M}^{-1}$ & 100,000 & $10^{7} \mathrm{M}^{-1}$ & $5000^{a}$ \\
\hline 16 & $10^{5} \mathrm{M}^{-1}$ & 50 & $10^{5} \mathrm{M}^{-1}$ & 3.333 \\
\hline 17 & $10^{5} \mathrm{M}^{-1}$ & 50 & $10^{5} \mathrm{M}^{-1}$ & 5 \\
\hline
\end{tabular}

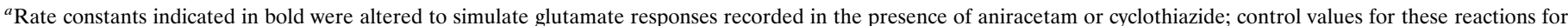
aniracetam or cyclothiazide are given in the corresponding columns for the other modulator.

from modulation by aniracetam, there should not be a linear correlation between modulation of deactivation and desensitization by cyclothiazide. The simulated data traces reproduce these features, with $\tau_{\text {deact }}(4.8 \mathrm{msec})$ slowed only 5.6-fold but desensitization essentially abolished. This is similar to data collected for GluRAi ( $\tau_{\text {deact }} 2.1 \mathrm{msec}$, 2.4-fold slower than control) but with $<6 \%$ desensitization within $100 \mathrm{msec}$. Figure $8 C$ shows that for the models developed the kinetics of recovery from the desensitized state are slow ( $\tau_{\text {rec }} 125 \mathrm{msec}$ ) with kinetics similar to those recorded experimentally for GluRA ( $\tau_{\text {rec }} 147 \mathrm{msec}$; Fig. $4 E$ ). Because GluRA $A_{i}$ desensitizes very little in the presence of cyclothiazide, it is difficult to assign a value for the "rate of onset of desensitization" as a measure of the efficacy of cyclothiazide. We therefore performed experiments to measure the dissociation rate of cyclothiazide in the presence of glutamate for GluRA $A_{i}\left(\tau_{\text {off }}\right.$ $15.7 \pm 0.7 \mathrm{sec})$ and for the model $\left(\tau_{\text {off }} 11.3 \mathrm{sec}\right.$; Fig. $\left.8 D\right)$ and found the rates of dissociation to be similar. Simulated doseresponse relationships with $1 \mathrm{~mm}$ glutamate as agonist yielded an $\mathrm{EC}_{50}$ for cyclothiazide of $1.0 \mu \mathrm{M}$ and a shift in the $\mathrm{EC}_{50}$ of the glutamate peak response from 936 to $26 \mu \mathrm{M}$ in the presence of 100 $\mu \mathrm{M}$ cyclothiazide. This substantially reproduces the results of Yamada and Tang (1993), for which the cyclothiazide $\mathrm{EC}_{50}$ was 12 $\mu \mathrm{M}$ with quisqualate as agonist, and the $\mathrm{EC}_{50}$ of the quisqualate peak response was shifted from 280 to $3 \mu \mathrm{M}$ in the presence of 10 $\mu \mathrm{M}$ cyclothiazide. The apparent stabilization of $\mathrm{RMA}_{2}$ as the underlying mechanism of modulation by cyclothiazide has been discussed previously for native AMPA receptors (Patneau et al., 1993; Kessler et al., 1996). It is supported by work demonstrating that there is no change in single-channel conductance in the presence of cyclothiazide (Yamada and Tang, 1993), by data that show a decrease in $\left[{ }^{3} \mathrm{H}\right]$ AMPA binding in the presence of cyclothiazide attributable to the higher affinity of AMPA for the desensitized state (Hall et al., 1993), and by the finding that cyclothiazide causes a leftward shift of kainate dose-response curves (Patneau et al., 1993; Partin et al., 1994). However, it is not possible with the present experiments to distinguish whether this occurs through a cyclothiazide-induced destabilization of the de- sensitized state, stabilization of the closed nondesensitized state $\left(\mathrm{RMA}_{2}\right)$, or a combination of both.

\section{DISCUSSION}

We report here a detailed analysis of a critical site in the alternatively spliced flip/flop domain of AMPA receptors (position 750 in GluRA) that affects intrinsic channel gating kinetics and the ability of three different compounds to modulate both desensitization and deactivation. These effects could reflect (1) coupling of deactivation and desensitization, (2) that structural determinants directing these conformational transitions share a set of amino acids (some of which are encoded within the flip/flop domain), and/or (3) that the modulators bind at or near this site. In the next section, we discuss our interpretation of the functional contributions of the flip/flop domain to AMPA receptor properties.

In the kinetic model presented in Figure 8, slowing the closing rate constant results in a concomitant slowing of the macroscopic rate of onset of desensitization (Vyklicky et al., 1991). As recently noted by Trussell and Otis (1996), experimental observations on AMPA receptors in different neuronal populations show a similar covariance between the time constants of deactivation and desensitization. Further support for this is shown in Figure $9 A$, which combines data from our study with published values for a large number of neuronal and recombinant AMPA receptors. Of the position 750 point mutations studied in detail, $S_{750} Q$ and $S_{750} A$ varied from GluRA in both $\tau_{\text {des }}$ and $\tau_{\text {deact }}$, whereas for $S_{750} N$ neither process was altered (Fig. $9 B$ ). This suggests that determinants at position 750 can directly influence the kinetics of deactivation, resulting in a secondary effect on the kinetics of desensitization. Although for native receptors heterogeneity in the rate of onset of desensitization would be expected to result from heterogeneity in the closing rate constant, the two kinetic processes do vary independently to some extent, perhaps according to subunit composition and assembly (Geiger et al., 1995). Evidence for variation in the rate of onset of desensitization, independent from the closing rate, is presented in Figure $9 \mathrm{~B}$. Wild-type GluRA $_{\mathrm{i}}$ and GluRA ${ }_{\mathrm{o}}$, both of which have a $\tau_{\text {deact }}$ of $0.8 \mathrm{msec}$, 
A

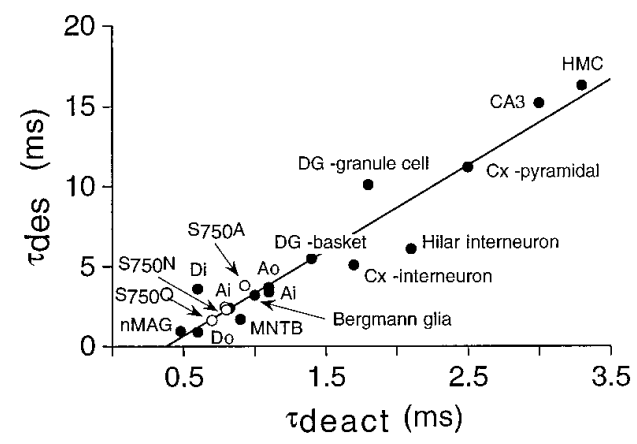

C

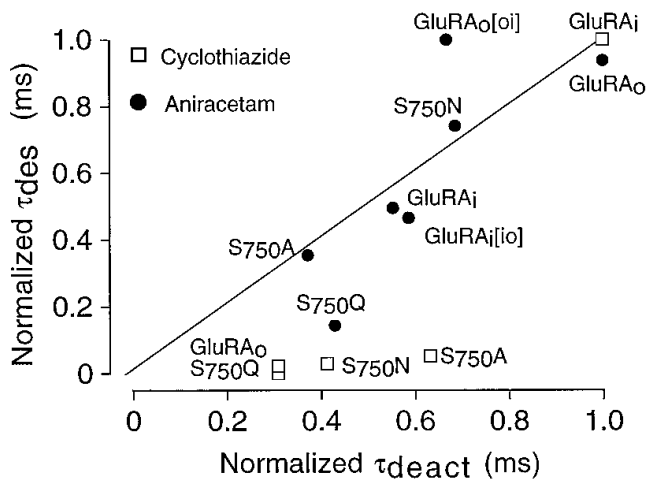

B

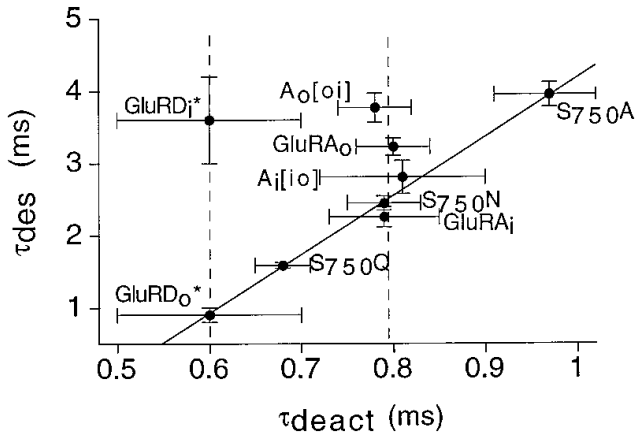

D

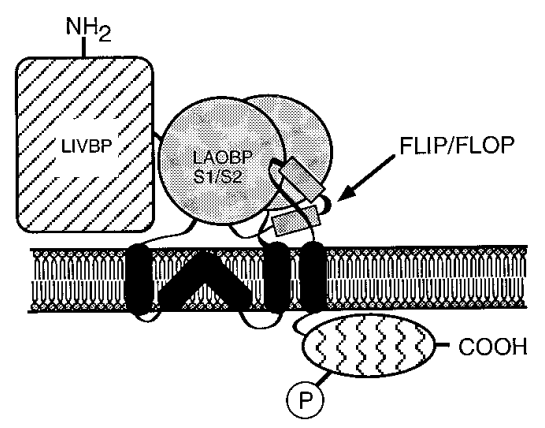

Figure 9. Deactivation and desensitization are linked processes. A, Correlation between the time constants for deactivation and desensitization combining previously published values for native and recombinant AMPA receptors $(\bullet)$ with data from the present study $(\bigcirc)$. HMC, Hilar mossy cells; $C A 3$, hippocampal CA3 pyramidal cells; $C x$-pyramidal, neocortical layer V pyramidal cells; Cx-interneuron, neocortical layer IV nonpyramidal cells; $D G$-basket, dentate gyrus basket cells; $M N T B$, medial nucleus of the trapezoid body (auditory nucleus). Values are taken from Geiger et al. (1995), except for nMAG (chick nucleus magnocellularis), which was taken from Raman and Trussell (1995) and recombinant GluRA $A_{i},-A_{o},-D_{i}$, and $-D_{o}\left(L_{0 m e l i}\right.$ et al., 1994). Data from the present study include GluRA $, S_{750} A, S_{750} N$, and $S_{750} Q$. Note that the time constants for outside-out patches presented in this study were obtained using $10 \mathrm{~mm}$ glutamate, whereas most previous studies used $1 \mathrm{~mm}$ glutamate. A linear fit through the data yields a slope of 5.3 $(r=0.96)$. A similar finding was reported recently by Trussell and Otis (1996). B, Comparison of the relationship between control deactivation and desensitization rates for mutations at position 750 or amino acids in the $\mathrm{C}$ terminus of the flip/flop domain (GluRA $\mathrm{A}_{\mathrm{i}}[\mathrm{io}]$ and $\left.\mathrm{GluRA}_{\mathrm{o}}[\mathrm{oi}]\right)$. A linear fit through GluRA $\mathrm{i}_{\mathrm{i}}$, $\mathrm{S}_{750} \mathrm{~N}, \mathrm{~S}_{750} \mathrm{Q}$, and $\mathrm{S}_{750} \mathrm{~A}$ yields a slope of $8.1(r=0.99)$. The asterisk indicates that data for GluRD are taken from Mosbacher et al. (1994). C, Comparison of the linear relationship between $\tau_{\text {deact }}$ and $\tau_{\text {des }}$ after making incremental changes in the closing rate constant for simulated data (solid line), and between $\tau_{\text {deact }}$ and $\tau_{\text {des }}$ in the presence of aniracetam $(\bullet)$ or cyclothiazide $(\square)$ for mutations described in this study. The data for aniracetam lie along the line, consistent with the hypothesis that aniracetam acts via slowing the closing rate constant. $D$, Schematic representation of AMPA receptor domains (O'Hara et al., 1993; Stern-Bach et al., 1994; Kuryatov et al., 1994). The N-terminal domain shares homology with LIVBP (bacterial periplasmic LeucineIsoleucine-Valine-Binding Protein; hatched region). The agonist-binding pocket is formed by two lobes (derived from N-terminal residues and residues from the M3-M4 extracellular loop) sharing homology with LAOBP (Lysine-Arginine-Ornithine-Binding Protein; gray stippled region); S1/S2 refers to the chimeric constructs (Stern-Bach et al., 1994; Kuusinen et al., 1995), confirming that this forms the agonist-binding pocket. Putative membrane domains shown in black are embedded within the lipid bilayer (Hollmann and Heinemann, 1994; Bennett and Dingledine, 1995). The cytoplasmic domain is shown with wavy hatching; $P$ represents the site for phosphorylation by CaM-kinase II (McGlade-McCulloh et al., 1993; Yakel et al., 1995). The flip/flop region is shown as a helix-turn-helix motif that connects the agonist-binding region to M4.

differ 1.3-fold in $\tau_{\text {des }}$ (Table 2). A more dramatic difference was reported for GluRD $\mathrm{i}_{\mathrm{i}}$ and GluRD ${ }_{\mathrm{o}}$, for which $\tau_{\text {deact }}$ is similar $(0.6$ msec), but for which $\tau_{\text {des }}$ differs fourfold between splice isoforms (Mosbacher et al., 1994).

To understand further the role of individual amino acids within the flip/flop region in directing conformational transitions underlying deactivation and desensitization, it would be instructive to know with what residues Ser $_{750}$ interacts. This is made difficult because the structural model based on bacterial amino acid-binding proteins is incomplete in this region. The downstream region has been modeled to fold back toward the 750 position (Stern-Bach et al., 1994), such that critical residues at the $\mathrm{C}$ terminus of the exon (KDSG/GGGD) may directly interact with position 750 to form a tertiary domain. Altered desensitization and deactivation kinetics may reflect changes in hydrogen bond interactions between the 750 position and the downstream region. For the two mutations that alter deactivation and desensitization kinetics in the opposite direction, Gln (larger than Ser) increases the rates whereas Ala (slightly smaller than Ser and aliphatic rather than hydrophilic) decreases the rates. Thus, Gln could permit a tighter interaction, whereas Ala could permit a weaker interaction, and these differences in packing might affect the conformational transitions underlying deactivation and desensitization. $\mathrm{S}_{750} \mathrm{D}$, the mutant for which no control response could be recorded, might reflect stabilization of a desensitized state attributable to a strong electrostatic interaction with the downstream region $\left(\right.$ KDSG in GluRA $\left.A_{i}\right)$. Our data suggest that within the flip/flop domain are determinants that can affect the rate of onset of desensitization via two mechanisms: (1) indirectly, by altering the rate of deactivation, as was seen with some of the 750 mutants; or (2) directly, by stabilizing the desensitized or nondesensitized conformation of the receptor.

How, then, might modulation of AMPA receptors occur? Fig- 
ure $9 C$ plots the relationship of $\tau_{\text {des }}$ and $\tau_{\text {deact }}$ from the kinetic model presented in Figure 8 , showing linear variation of $\tau_{\mathrm{des}}$ and $\tau_{\text {deact }}$, with a twofold slowing of the closing rate constant resulting in a fourfold slowing of $\tau_{\mathrm{des}}$. Also plotted are experimental values for modulation of deactivation and desensitization by aniracetam and cyclothiazide for the mutations studied in this paper (Table 2). The data points for aniracetam tend to lie along the line predicted for changing the closing rate constant $(r=0.81)$, whereas the data points for cyclothiazide modulation do not. Our interpretation is that the mutants bind aniracetam with different affinities, which results in different efficacies for modulation but via a common mechanism: slowing the closing rate constant. With our kinetic model, modulation of deactivation and desensitization becomes less efficacious, with a range similar to that observed for the point mutants analyzed, as the $K_{\mathrm{d}}$ for aniracetam is decreased 10- to 100-fold (data not shown). Direct measurement of the binding constants of $\left[{ }^{3} \mathrm{H}\right]$ aniracetam for the mutations would be a conclusive test of this, but binding experiments with radiolabeled aniracetam are confounded by both low-affinity binding and high nonspecific binding such that effects of the point mutations would be unlikely to be resolved (Fallarino et al., 1995). The data for cyclothiazide do not fall on the line describing a concomitant variation of desensitization and deactivation that results from slowing the closing rate constant (Fig. 9C). Rather, we find that there is a nonlinear correlation between modulation of deactivation and desensitization by cyclothiazide that could be explained if cyclothiazide acts by stabilizing the nondesensitized closed state, which changes apparent agonist affinity, availability to the open state, and entry into the desensitized state. Aniracetam does not modulate desensitization directly and, therefore, would not modulate $\mathrm{S}_{750} \mathrm{D}$, the mutation thought to stabilize the desensitized state, whereas cyclothiazide should, consistent with our experimental findings. The simplest interpretation of the experiments reported here is that cyclothiazide, aniracetam, and thiocyanate bind at or near the flip/flop region but that the determinants of binding and mechanisms of modulation are different, as seen by the results of the mutational analysis of position 750 (Figs. 3, 6; Table 1). The positive allosteric site to which cyclothiazide and aniracetam bind is different from, but may be close to, a negative allosteric site that binds GYKI 53655 (Johansen et al., 1995; Partin and Mayer, 1996; Rammes et al., 1996; Yamada and Turetsky, 1996). Thiocyanate has an allosteric effect on the transition between the closed and the desensitized states (Kessler et al., 1996), and we show here that this effect can be positive or negative depending on the residue at position 750 .

Deactivation and desensitization are two mechanisms by which glutamate receptors terminate the flow of ions through the channel. Both processes entail transduction of an allosteric signal from the agonist-binding pocket to the pore. The flip/flop domain resides just before M4 (Fig. 9D), and our data suggest that this region is either a necessary component of or tightly coupled to signal transduction between the agonist-binding pocket and the pore, because amino acid substitutions in this region affect both deactivation and desensitization. Bacterial periplasmic amino acid-binding proteins have been used with great success as templates for structural homology modeling of glutamate receptors yet, unlike ion channels, they do not encode their own membrane domains and, instead, associate with membrane proteins mediating amino acid transport (Ames, 1986). The structural homology between LAOBP and GluR3, for example, ends with the helixturn-helix motif within the flip/flop domain (Fig. 1) and does not extend to the downstream set of four amino acids (KDSG/
GGGD) at the C terminus of the alternative exon (Stern-Bach et al., 1994). One explanation for this divergence could be adaptation of the amino acids encoded in the flip/flop region to a new function, signal transduction to the pore. Binding of modulators would impede transduction of the signal, either by stabilizing one conformation or by destabilizing another. In this hypothesis, the signal from the flip/flop domain to the pore could be mediated via M4, possibly through a re-alignment of M1-M4 contacts, as has been postulated for acetylcholine receptors (Unwin, 1993). Molecular modeling experiments have suggested that there may be a Cys bridge between residues 714 and 769 (Sutcliffe et al., 1996), which could be the means by which the flip/flop domain is anchored with respect to the agonist-binding domain.

The kinetics of deactivation and desensitization of homooligomeric GluRA $A_{i}$ and GluRA ${ }_{o}$ and other homo-oligomeric receptors (Mosbacher et al., 1994) are faster than the kinetics observed in hippocampal neurons (Vyklicky et al., 1991; Colquhoun et al., 1992; Patneau et al., 1993; Fleck et al., 1996) and are somewhat similar to the kinetics reported for the chick nMAG neurons (Raman and Trussell, 1992), rat MNTB relay neurons, and Bergmann glia (Geiger et al., 1995). We found that for GluRA receptors the sojourn through the open, closed, and desensitized states could occur within $1 \mathrm{msec}$ when activated by glutamate, which is consistent with the utilization of a fast open state described by Raman and Trussell (1995). However, the responses from GluRA were very much slower to recover from desensitization, with $\tau_{\text {rec }}$ of $147 \mathrm{msec}$ versus $16 \mathrm{msec}$ found in nMAG neurons. The differences between the kinetics of recombinant homo-oligomers and native receptors must be attributable to altered properties when subunits hetero-oligomerize, particularly when the complex includes GluRB or GluRD (Lomeli et al., 1994). One remarkable feature of GluRA is the extent to which the desensitization properties of homomeric GluRA $A_{i}$ and GluRA differ from hetero-oligomeric complexes of GluRA $\mathrm{B}_{i}$ and GluRA $_{\text {o }}$ o (Sommer et al., 1990; Lomeli et al., 1994; Partin et al., 1994). The similarities and differences between native and recombinant receptors emphasize the concept that functional heterogeneity of glutamatergic synapses is directed by heterogeneity in subunit composition and assembly and by differential RNA splicing/editing of individual subunits. The experiments described here confirm the functional importance of the flip/flop domain in regulating intrinsic channel kinetics as well as modulation of desensitization and deactivation, and emphasize the significance of alternative splicing as a means of expanding the diverse repertoire of AMPA receptor-mediated synaptic responses.

\section{REFERENCES}

Ames GF-L (1986) Bacterial periplasmic transport systems: structure, mechanism, and evolution. Annu Rev Biochem 55:397-425.

Arai A, Silberg J, Kessler M, Lynch G (1995) Effect of thiocyanate on AMPA receptor mediated responses in excised patches and hippocampal slices. Neuroscience 66:815-827.

Barbour B, Keller BU, Llano I, Marty A (1994) Prolonged presence of glutamate during excitatory synaptic transmission to cerebellar Purkinje cells. Neuron 12:1331-1343.

Bennett JA, Dingledine R (1995) Topology profile for a glutamate receptor: three transmembrane domains and a channel-lining re-entrant membrane loop. Neuron 14:373-384.

Benveniste M, Clements J, Vyklicky L, Mayer ML (1990) A kinetic analysis of the modulation of $N$-methyl-D-aspartic acid receptors by glycine in mouse cultured hippocampal neurones. J Physiol (Lond) 428:333-357.

Bertolino M, Baraldi M, Parenti C, Braghiroli D, DiBella M, Vicini S, Costa E (1993) Modulation of AMPA/kainate receptors by analogues 
of diazoxide and cyclothiazide in thin slices of rat hippocampus. Receptors Channels 1:267-278.

Bochet P, Audinat E, Lambolez B, Crepel F, Rossier J, Iino M, Tsuzuki K, Ozawa S (1994) Subunit composition at the single-cell level explains functional properties of a glutamate-gated channel. Neuron 12:383-388.

Boulter J, Hollmann M, O'Shea-Greenfield A, Hartley M, Deneris E, Maron C, Heinemann S (1990) Molecular cloning and functional expression of glutamate receptor subunit genes. Science 249:1033-1037.

Bowie D, Smart TG (1993) Thiocyanate ions selectively antagonize AMPA-evoked responses in Xenopus laevis oocytes microinjected with rat brain mRNA. Br J Pharmacol 109:779-787.

Burnashev N, Khodorova A, Jonas P, Helm PJ, Wisden W, Monyer H, Seeburg PH, Sakmann B (1992) Calcium-permeable AMPA-kainate receptors in fusiform cerebellar glial cells. Science 256:1566-1570.

Chalfie M, Tu Y, Euskirchen G, Ward WW, Prasher DC (1994) Green fluorescent protein as a marker for gene expression. Science 263:802-805.

Chen C, Okayama H (1987) High-efficiency transformation of mammalian cells by plasmid DNA. Mol Cell Biol 7:2745-2752.

Colquhoun D, Jonas P, Sakmann B (1992) Action of brief pulses of glutamate on AMPA/kainate receptors in patches from different neurones of rat hippocampal slices. J Physiol (Lond) 458:261-287.

Cubitt AB, Heim R, Adams SR, Boyd AE, Gross LA, Tsien RY (1995) Understanding, improving and using green fluorescent proteins. Trends Biochem Sci 20:448-455.

Edmonds B, Gibb AJ, Colquhoun D (1995) Mechanisms of activation of glutamate receptors and the time course of excitatory synaptic currents. Annu Rev Physiol 57:495-519.

Fallarino F, Genazzani AA, Silla S, L'Episcopo MR, Camici O, Corazzi L, Nicoletti F, Fioretti MC (1995) $\left[{ }^{3} \mathrm{H}\right]$ aniracetam binds to specific recognition sites in the brain. J Neurochem 65:912-908.

Fleck MW, Bähring R, Patneau DK, Mayer ML (1996) AMPA receptor heterogeneity in rat hippocampal neurons revealed by differential sensitivity to cyclothiazide. J Neurophysiol 75:2322-2333.

Geiger JRP, Melcher T, Koh DS, Sakmann B, Seeburg PH, Jonas P, Monyer H (1995) Relative abundance of subunit mRNAs determines gating and $\mathrm{Ca}^{2+}$ permeability of AMPA receptors in principle neurons and interneurons in rat CNS. Neuron 15:193-204.

Gouliaev AH, Senning A (1994) Piracetam and other structurally related nootropics. Brain Res 19:180-222.

Hall RA, Kessler M, Quan A, Ambros-Ingerson J, Lynch G (1993) Cyclothiazide decreases $\left[{ }^{3} \mathrm{H}\right]$ AMPA binding to rat brain membranes: evidence that AMPA receptor desensitization increases agonist affinity. Brain Res 628:345-348.

Hestrin S (1992) Activation and desensitization of glutamate-activated channels mediating fast excitatory synaptic currents in the visual cortex. Neuron 9:991-999.

Hollmann M, Heinemann S (1994) Cloned glutamate receptors. Annu Rev Neurosci 17:31-108.

Hollmann M, Maron C, Heinemann S (1994) N-glycosylation site tagging suggests a three transmembrane domain topology for the glutamate receptor GluR1. Neuron 13:1331-1343.

Howe JR, Cull-Candy SG, Colquhoun D (1991) Currents through single glutamate receptor channels in outside-out patches from rat cerebellar granule cells. J Physiol (Lond) 432:143-202.

Isaacson JS, Nicoll RA (1991) Aniracetam reduces glutamate receptor desensitization and slows the decay of fast excitatory synaptic currents in the hippocampus. Proc Natl Acad Sci USA 88:10936-10940.

Johansen TH, Chaudhary A, Verdoorn TA (1995) Interactions among GYKI-52466, cyclothiazide, and aniracetam at recombinant AMPA and kainate receptors. Mol Pharmacol 48:946-955.

Jonas P, Sakmann B (1992) Glutamate receptor channels in isolated patches from CA1 and CA3 pyramidal cells of rat hippocampal slices. J Physiol (Lond) 455:143-171.

Jones MV, Westbrook GL (1995) Desensitized states prolong GABA channel responses to brief agonist pulses. Neuron 15:181-191.

Keinänen K, Wisden W, Sommer B, Werner P, Herb A, Verdoorn TA, Sakmann B, Seeburg PH (1990) A family of AMPA-selective glutamate receptors. Science 249:556-560.

Kessler M, Arai A, Quan A, Lynch G (1996) Effect of cyclothiazide on binding properties of AMPA-type glutamate receptors: lack of competition between cyclothiazide and GYKI 52466. Mol Pharmacol 49:123-131.
Kuryatov A, Laube B, Betz H, Kuhse J (1994) Mutational analysis of the glycine-binding site of the NMDA receptor: structural similarity with bacterial amino acid-binding proteins. Neuron 12:1291-1300.

Kuusinen A, Arvola M, Keinänen K (1995) Molecular dissection of the agonist binding site of an AMPA receptor. EMBO J 14:6327-6332.

Lambolez B, Audinat E, Bochet P, Crepel F, Rossier J (1992) AMPA receptor subunits expressed by single Purkinje cells. Neuron 9:247-258.

Liu Y, Dilger JP (1991) Opening rate of acetylcholine receptor channels. Biophys J 60:424-432.

Livsey CT, Costa E, Vicini S (1993) Glutamate-activated currents in outside-out patches from spiny versus aspiny hilar neurons of rat hippocampal slices. J Neurosci 13:5324-5333.

Lomeli H, Mosbacher J, Melcher T, Höger T, Geiger JRP, Kuner T, Monyer H, Higuchi M, Bach A, Seeburg PH (1994) Control of kinetic properties of AMPA receptor channels by nuclear RNA editing. Science 266:1709-1713.

McGlade-McCulloh E, Yamamoto H, Tan SE, Brickey DA, Soderling TR (1993) Phosphorylation and regulation of glutamate receptors by calcium/calmodulin-dependent protein kinase II. Nature 362:640-642.

Monyer H, Seeburg PH, Wisden W (1991) Glutamate-operated channels: developmentally early and mature forms arise by alternative splicing. Neuron 6:799-810.

Mosbacher J, Schoepfer R, Monyer H, Burnashev N, Seeburg P, Ruppersberg JP (1994) A molecular determinant for submillisecond desensitization in glutamate receptors. Science 266:1059-1062.

O'Hara PJ, Sheppard PO, Thogersen H, Venezia D, Haldeman BA, McGrane V, Houamed KM, Thomsen C, Gilbert TL, Mulvihill ER (1993) The ligand-binding domain in metabotropic glutamate receptors is related to bacterial periplasmic binding proteins. Neuron 11:41-52.

Partin KM, Patneau DK, Mayer ML (1994) Cyclothiazide differentially modulates desensitization of AMPA receptor splice variants. Mol Pharmacol 46:129-138.

Partin KM, Mayer ML (1996) Negative allosteric modulation of wildtype and mutants AMPA receptors by GYKI 53655. Mol Pharmacol 49:142-148.

Partin KM, Bowie D, Mayer ML (1995) Structural determinants of allosteric regulation in alternatively spliced AMPA receptors. Neuron 14:833-843.

Patneau DK, Vyklicky L, Mayer ML (1993) Hippocampal neurons exhibit cyclothiazide-sensitive rapidly desensitizing responses to kainate. J Neurosci 13:3496-3509.

Raman IM, Trussell LO (1992) The kinetics of the response to glutamate and kainate in neurons of the avian cochlear nucleus. Neuron 9:173-186.

Raman IM, Trussell LO (1995) The mechanism of alpha-amino-3hydroxy-5-methyl-4-isoxazoleproprionate receptor desensitization after removal of glutamate. Biophys J 68:137-146.

Rammes G, Swandulla D, Collingridge GL, Hartmann S, Parsons CG (1996) Interactions of 2,3-benzodiazepines and cyclothiazide at AMPA receptors: patch clamp recordings in cultured neurones and area CA1 in hippocampal slices. Br J Pharmacol 117:1209-1221.

Sommer B, Keinänen K, Verdoorn TA, Wisden W, Burnashev N, Herb A, Köhler M, Takagi T, Sakmann B, Seeburg PH (1990) Flip and flop: a cell-specific functional switch in glutamate-operated channels of the CNS. Science 249:1580-1585.

Staubli U, Perez Y, Xu FB, Rogers G, Ingvar M, Stone-Elander S, Lynch G (1994a) Centrally active modulators of glutamate receptors facilitate the induction of long-term potentiation in vivo. Proc Natl Acad Sci USA 91:11158-11162.

Staubli U, Rogers G, Lynch G (1994b) Facilitation of glutamate receptors enhances memory. Proc Natl Acad Sci USA 91:777-781.

Stern-Bach Y, Bettler B, Hartley M, Sheppard PO, O'Hara PJ, Heinemann SF (1994) Agonist-selectivity of glutamate receptors is specified by two domains structurally related to bacterial amino acid binding proteins. Neuron 13:1345-1357.

Sutcliffe M, Wo ZG, Oswald RE (1996) Three-dimensional models of non-NMDA glutamate receptors. Biophys J 70:1575-1589.

Tang C-M, Shi Q-Y, Katchman A, Lynch G (1991) Modulation of the time course of fast EPSCs and glutamate channel kinetics by aniracetam. Science 254:288-290.

Tong G, Jahr CE (1994) Regulation of glycine-insensitive desensitization of the NMDA receptor in outside-out patches. J Neurophysiol 72:754-761.

Trussell LO, Otis TS (1996) Physiology of AMPA receptors: biophysical 
characteristics that subserve integrative roles of synapses. In: Excitatory amino acids and the cerebral cortex (Conti F, Hicks TP, eds), pp 63-72. Cambridge: MIT.

Unwin N (1993) Nicotinic acetylcholine receptor at $9 \AA$ resolution. J Mol Biol 229:1101-1124.

Vyklicky L, Benveniste M, Mayer ML (1990) Modulation of N-methylD-aspartic acid receptor desensitization by glycine in mouse cultured hippocampal neurones. J Physiol (Lond) 428:313-331.

Vyklicky L, Patneau DK, Mayer ML (1991) Modulation of excitatory synaptic transmission by drugs that reduce desensitization at AMPA kainate receptors. Neuron 7:971-984.

Yakel JL, Vissavajjhala P, Derkach VA, Brickey DA, Soderling TR (1995) Identification of a $\mathrm{Ca}^{2+} /$ calmodulin-dependent protein kinase II regulatory phosphorylation site in non-NMDA receptors. Proc Natl Acad Sci USA 92:1376-1380.
Yamada KA, Rothman SM (1992) Diazoxide reversibly blocks glutamate desensitization and prolongs excitatory postsynaptic currents in rat hippocampal neurons. J Physiol (Lond) 458:385-407.

Yamada K, Tang CM (1993) Benzothiadiazines inhibit rapid glutamate receptor desensitization and enhance glutamatergic synaptic currents. J Neurosci 13:3904-3915.

Yamada KA, Turetsky DM (1996) Allosteric interactions between cyclothiazide and AMPA receptor antagonists. $\mathrm{Br} \mathrm{J}$ Pharmacol 117:1663-1672.

Zivkovic D, Thompson DM, Bertolino M, DiBella M, Costa E, Guidotti A (1995) 7-Chloro-3-methyl-3,4-dihydro-2H-1,2,4-benzothiadiazine $S, S$-dioxide (IDRA21): a benzothiadiazine derivative that enhances cognition by attenuating DL-amino-2,3-dihydro-5-methyl-3-oxo-4isoxazolepropanoic acid (AMPA) receptor desensitization. J Pharmacol Exp Ther 272:300-309. 